\title{
Interactions between wild-type and mutant prion proteins modulate neurodegeneration in transgenic mice
}

\author{
Glenn C. Telling, ${ }^{1}$ Takeshi Haga, ${ }^{1}$ Marilyn Torchia, ${ }^{1}$ Patrick Tremblay, ${ }^{1}$ Stephen J. DeArmond, ${ }^{1,3}$ \\ and Stanley B. Prusiner ${ }^{1,3,4}$ \\ ${ }^{1}$ Department of Neurology, ${ }^{2}$ Department of Biochemistry and Biophysics, ${ }^{3}$ Department of Pathology, University of \\ California at San Francisco, San Francisco, California 94143 USA
}

Transgenic mice overexpressing approximately eightfold the mouse (Mo) prion protein (PrP) gene carrying the P102L mutation of GSS developed neurodegeneration between 150 and 300 days of age, while controls expressing the wild-type MoPrP-A transgene at the same level remained healthy. Mice overexpressing the wild-type MoPrP-A transgene were highly susceptible to inoculated mouse prions, exhibiting abbreviated scrapie incubation times of 45 days. After crossing the mutant transgene onto a null (Prnp ${ }^{0 / 0}$ ) background, the resulting $\operatorname{Tg}\left(\mathrm{MoPrP}_{\mathrm{P}} \mathrm{P101 \textrm {L }}\right) \mathrm{Prnp}^{\mathrm{o} / 0}$ mice displayed a highly synchronous onset of illness at 145 days of age, which was shortened to 85 days upon breeding to homozygosity for the transgene array. Besides occasional PrP plaques and modest spongiform degeneration, $\mathrm{Tg}(\mathrm{MoPrP}-\mathrm{P} 101 \mathrm{~L})$ mice suffered from a myopathy and a peripheral neuropathy. Disruption of the wild-type MoPrP gene increased the number of PrP plaques and the severity of spongiform degeneration. Brain extracts prepared from spontaneously ill transgenic mice transmitted disease to $\mathrm{Tg} 196 / \mathrm{Prnp}^{\mathrm{o} / 0}$ mice, expressing low levels of the mutant transgene. Our results demonstrate that the presence of wild-type PrP genes, the level of PrP transgene expression, and the sequence of the transgene can profoundly modify experimental prion disease.

[Key Words: Prions; neurodegeneration; scrapie; transgenic mice]

Received April 2, 1996; revised version accepted June 3, 1996.

The prion diseases are unique in that they present as sporadic, inherited, and infectious disorders (Ridley et al. 1986; Prusiner 1989; Richardson and Masters 1995). For many years, they were classified as slow virus infections (Sigurdsson 1954; Gajdusek 1977). Although much emphasis was placed on the transmissible nature of the prion diseases for many decades, studies of the inherited aspects of these disorders are now well appreciated /for review, see Brown et al. 1991; Prusiner 1994; Gambetti et al. 1995).

Nineteen different mutations of the prion protein $(\operatorname{PrP})$ gene that result in non-conservative substitutions or insertions have been identified in families with a history of inherited central nervous system (CNS) disease. Genetic linkage of a P102L mutation to Gerstmann-SträusslerScheinker disease (GSS) established that familial prion diseases are hereditary disorders and provided a novel mechanism to explain how the prion diseases could manifest as both genetic and infectious illnesses (Hsiao et al. 1989; Prusiner 1989). The discovery of a mutation at codon 102 in the PrP gene that is responsible for this dominantly inherited disease, permits unambiguous di-

${ }^{4}$ Corresponding author. agnosis during life as well as identification of individuals at risk.

In our initial attempt to model GSS in transgenic mice, we constructed a mutated cosmid clone containing the Prnp ${ }^{b}$ gene from the ILn/J mouse (Hsiao et al. 1990). The resulting clone encoded mouse PrP-A (MoPrP-A) with a substitution of leucine for proline at codon 101 designated $\mathrm{P} 101 \mathrm{~L}$, which corresponds to codon 102 in human $\operatorname{PrP}(\mathrm{HuPrP})$. Two lines of these mice developed CNS dysfunction between 50 and 300 days of age. That overexpression of Syrian hamster ( $\mathrm{SHa}$ ) PrP and wild-type MoPrP-B can produce neurodegeneration of the CNS as well as neuromyopathy (Westaway et al. 1994) forced us to re-examine neurodegeneration in Tg(MoPrP-P101L) mice (Hsiao et al. 1990). We constructed additional lines of $\mathrm{Tg}(\mathrm{MoPrP}-\mathrm{P} 101 \mathrm{~L})$ mice as well as control lines of $\mathrm{Tg}(\mathrm{MoPrP}-\mathrm{A})$ mice. Mice overexpressing wild-type MoPrP-A remained well for $>600$ days, in contrast to those overexpressing MoPrP-P101L, all of which become ill between 150 and 300 days of age.

The wide range in the age of onset of spontaneous illness in these $\mathrm{Tg}(\mathrm{MoPrP}-\mathrm{P} 101 \mathrm{~L})$ mice contrasts with experimental scrapie, in which incubation times for a group of animals receiving the same inoculum are 
always similar. We produced high-copy-number $\mathrm{Tg}(\mathrm{MoPrP}-\mathrm{P} 101 \mathrm{~L})$ mice on a background in which the wild-type MoPrP gene had been ablated by gene targeting $\left\langle\right.$ Prnp $^{0 / 0}$ ) (Büeler et al. 1992). Prnp ${ }^{0 / 0}$ mice, which do not express MoPrP, are resistant to mouse prions (Büeler et al. 1993; Prusiner et al. 1993; Manson et al. 1994; Sakaguchi et al. 1995). The resulting Tg(MoPrP-P101L)Prnp $^{0 / 0}$ mice exhibited a remarkable uniformity in the timing of their onset of illness, a shorter mean duration of illness and neuropathologic changes characterized by numerous $\operatorname{PrP}$ plaques. Brain extracts prepared from spontaneously ill $\mathrm{Tg}(\mathrm{MoPrP}-\mathrm{P} 101 \mathrm{~L})$ mice reproducibly transmitted CNS degeneration to low-copy-number $\mathrm{Tg}$ (MoPrP-P101L)196 mice $\sim 350$ days after intracerebral inoculation. Crossing of $\mathrm{Tg}(\mathrm{MoPrP}-\mathrm{P} 101 \mathrm{~L}) 196$ mice onto the null background shortened these incubation times to $\sim 200$ days. Uninoculated Tg196/FVB mice and Tg196/ $\mathrm{Prnp}^{0 / 0}$ mice did not develop spontaneous CNS disease nor did Tg196/FVB mice and Tg196/Prnp ${ }^{0 / 0}$ mice inoculated with brain extracts from healthy nontransgenic control littermates. Comparison of muscle and peripheral nerve from spontaneously ill $\mathrm{Tg}(\mathrm{MoPrP}-\mathrm{P} 101 \mathrm{~L})$ mice, age-matched $\mathrm{Tg}(\mathrm{MoPrP}-\mathrm{P} 101 \mathrm{~L}) 196$ and aged $\mathrm{Tg}$ (MoPrP-A) mice revealed that overexpression of MoPrPP101L, but not wild-type MoPrP-A, resulted in pathological abnormalities in muscle and peripheral nerve in addition to neurodegeneration of the CNS. These results demonstrate that disease in $\operatorname{Tg}(\operatorname{MoPrP}-\mathrm{P} 101 \mathrm{~L})$ mice is caused specifically by the adverse effects of mutant $\operatorname{PrP}$ rather than overexpression of PrP encoded by the transgene.

\section{Results}

\section{Mutant and wild-type MoPrP transgenes}

We constructed a series of $\mathrm{Tg}(\mathrm{MoPrP}-\mathrm{P} 101 \mathrm{~L})$ mice using fertilized eggs from FVB mice. The resulting mice express transgene-derived mutant MoPrP-P101L and endogenous wild-type MoPrP. The Tg(MoPrP-P101L)/FVB mice differ from $\mathrm{Tg}(\mathrm{MoPrP}-\mathrm{P} 101 \mathrm{~L}) 87$ and $\mathrm{Tg}(\mathrm{MoPrP}$ P101L)174 mice produced earlier using fertilized eggs from a $(\mathrm{C} 57 \mathrm{BL} \times \mathrm{SJL}) \mathrm{F} 2$ cross. In addition, the cosSHa.Tet vector used to construct the $\mathrm{Tg}(\mathrm{MoPrP}-\mathrm{P} 101 \mathrm{~L} / \mathrm{FVB}$ mice differs from the ILn/J cosmid clone used in our initial studies (Hsiao et al. 1990).

Founder transgenic mice were generated by microinjection of linearized DNA from the cosSHa. Tet constructs, eight expressing MoPrP(P101L $)$ designated $\mathrm{Tg}(\mathrm{MoPrP}-\mathrm{P} 101 \mathrm{~L}) / \mathrm{FVB}$ and two expressing wild-type mouse $\operatorname{PrP}^{\mathrm{C}}$-A designated $\mathrm{Tg}(\mathrm{MoPrP}-\mathrm{A}) / \mathrm{FVB}$. Three $\mathrm{Tg}(\mathrm{MoPrP}-\mathrm{P} 101 \mathrm{~L}) / \mathrm{FVB}$ lines and one Tg(MoPrP-A $) / \mathrm{FVB}$ line were established. We estimated that levels of $\operatorname{PrP}^{\mathrm{C}}$ in the brains of mice from two lines expressing MoPrPP101L, designated Tg(MoPrP-P101L)2247/FVB and $\mathrm{Tg}($ MoPrP-P101L)2866/FVB, and one line expressing wild-type mouse $\operatorname{PrP}^{\mathrm{C}}$-A, designated $\mathrm{Tg}(\mathrm{MoPrP}-\mathrm{A}) 4053$ / $\mathrm{FVB}$, were each about eightfold higher than $\operatorname{Pr} \mathrm{P}^{\mathrm{C}}$ levels in the brains of nontransgenic mice. The fourth line overexpressing MoPrP-P101L $\sim 32$-fold was designated $\mathrm{Tg}($ MoPrP-P101L)2862/FVB.
Expression of MoPrP-P101L transgene produces CNS degeneration

Because wild-type and mutant MoPrP are overexpressed at equivalent levels in the brains of $\mathrm{Tg}(\mathrm{MoPrP}-\mathrm{A}) 4053 /$ FVB, $\mathrm{Tg}$ (MoPrP-P101L)2866/FVB, and Tg(MoPrP-P101L)$2247 /$ FVB mice, we were able to assess the relative contributions of the $\operatorname{MoPrP}(\mathrm{P} 101 \mathrm{~L})$ mutation and $\operatorname{PrP}$ overexpression upon the development of spontaneous neurologic disease. In contrast to the $\mathrm{Tg}(\mathrm{MoPrP}-\mathrm{A}) 4053 / \mathrm{FVB}$ mice, which remained free of CNS dysfunction for $>600$ days of age, the $\mathrm{Tg}(\mathrm{MoPrP}-\mathrm{P} 101 \mathrm{~L}) 2247 / \mathrm{FVB}$ and $\mathrm{Tg}$ (MoPrP-P101L)2862/FVB lines began to exhibit ataxia, rigidity, and lethargy between 150 and 200 days of age (Fig. 1). By 300 days, $100 \%$ of Tg(MoPrP-P101L)2247/FVB mice had developed CNS dysfunction while $\sim 410$ days was required for all of the $\mathrm{Tg}(\mathrm{MoPrP}-\mathrm{P} 101 \mathrm{~L}) 2862 / \mathrm{FVB}$ mice to exhibit signs of CNS degeneration. The mean age of disease was $227 \pm 16$ days ( \pm S.E.M.) and 321 \pm 21 days in $17 \mathrm{Tg}($ MoPrP-P101L)2247/FVB and 14 $\mathrm{Tg}(\mathrm{MoPrPP} 101 \mathrm{~L}) 2862 / \mathrm{FVB}$ mice, respectively (Table 1). Nontransgenic littermates of the $\mathrm{Tg}(\mathrm{MoPrP}-\mathrm{P} 101 \mathrm{~L}) / \mathrm{FVB}$ lines remained asymptomatic for $>600$ days.

The ages of onset of neurologic dysfunction in $\mathrm{Tg}$ (MoPrP-P101L)2866/FVB mice were indistinguishable from those in $\mathrm{Tg}(\mathrm{MoPrP}-\mathrm{P} 101 \mathrm{~L}) 2247 / \mathrm{FVB}$ (Fig. 1A, B); both of these $\operatorname{Tg}(\operatorname{MoPrP}-\mathrm{P} 101 \mathrm{~L})$ lines overexpress the transgene about eightfold. The mean age of disease was $220 \pm 10$ days in $18 \mathrm{Tg}($ MoPrP-P101L)2866/FVB mice (Table 1). Because Tg(MoPrP-A)4053/FVB, Tg(MoPrPP101L)2247/FVB, and Tg(MoPrP-P101L)2866/FVB mice all express wild-type or mutant $\mathrm{MoPrP}^{\mathrm{C}}$ at the same levels, we conclude that overexpression of $\operatorname{PrP}$ cannot account for the spontaneous development of neurologic symptoms in $\operatorname{Tg}(\mathrm{MoPrP}-\mathrm{P} 101 \mathrm{~L})$ mice; rather, expression of $\mathrm{MoPr}(\mathrm{P} 101 \mathrm{~L})$ is required for CNS disease in these transgenic mice.

The $\operatorname{Tg}(\mathrm{MoPrP}-\mathrm{P} 101 \mathrm{~L}) 87$ and $\operatorname{Tg}(\mathrm{MoPrP}-\mathrm{P} 101 \mathrm{~L}) 174$ mice were constructed with a modified ILn/J mouse cosmid (Hsiao et al. 1990; Hsiao et al. 1994), whereas the $\mathrm{Tg}$ (MoPrP-P101L)2247/FVB and Tg(MoPrP-P101L)2866/ FVB mice were produced using cosSHa.Tet vector. An additional difference between the sets of transgenic lines is that the $\mathrm{Tg}(\mathrm{MoPrP}-\mathrm{P} 101 \mathrm{~L}) 87$ and $\mathrm{Tg}(\mathrm{MoPrP}-$ P101L)174 mice were derived from outbred (C57BL/ $6 \times$ SJL)F2 fertilized oocytes, whereas the Tg(MoPrPP101L)2247/FVB and Tg(MoPrP-P101L)2866/FVB mice were derived from inbred FVB fertilized oocytes. Because all four transgenic lines display indistinguishable CNS degeneration, it is likely that the substitution of $L$ for $P$ at residue 101 is the only cause of the illness. Additional support comes from transgenic mice expressing chimeric mouse/human MHu2M PrP with the P101L mutation which also spontaneously develop CNS disease. Breeding these $\mathrm{Tg}(\mathrm{MHu} 2 \mathrm{M}-\mathrm{P} 101 \mathrm{~L}) 69$ mice to transgene homozygosity shortened the mean age of illness from 362 \pm 13 ( \pm S.E.M.) to $199 \pm 2$ days (Telling et al. 1995; G. Telling and S.B. Prusiner, unpubl.).

The $\mathrm{Tg}($ MoPrP-P101L)2862/FVB line that overexpresses mutant $\operatorname{PrP} \sim 32$-fold is of interest because we 

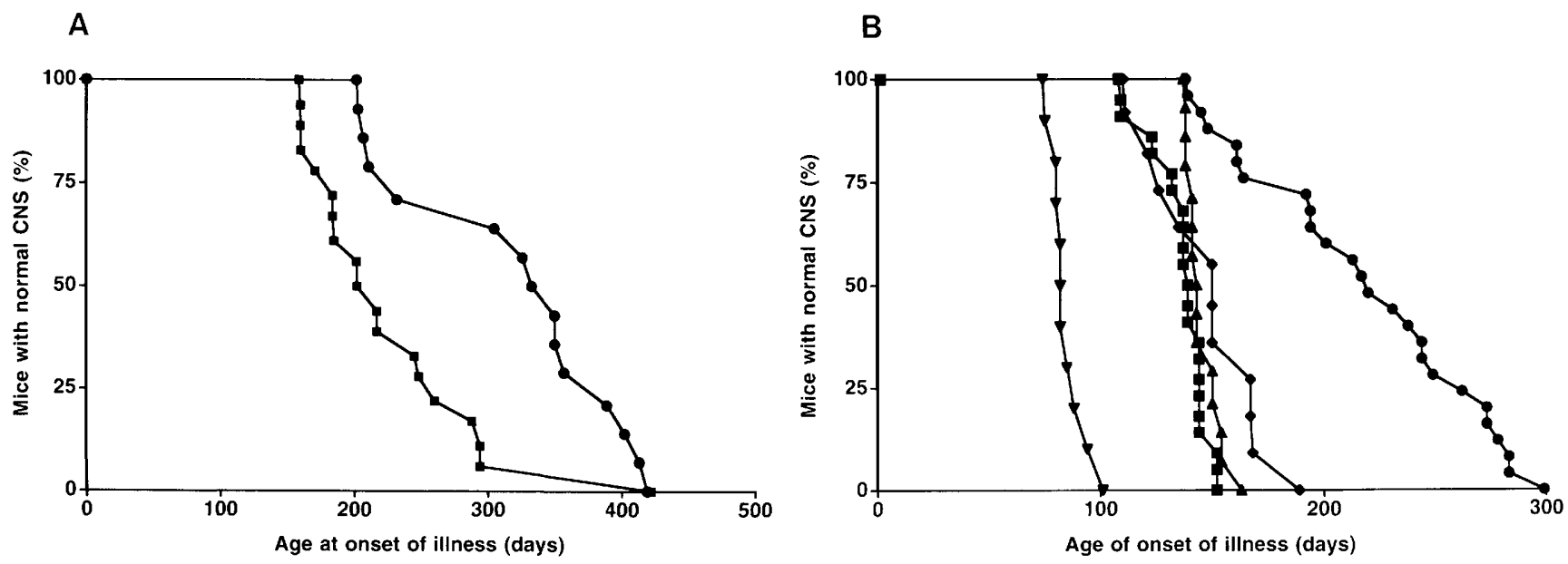

Figure 1. Spontaneous neurologic disease in $\operatorname{Tg}(\mathrm{MoPrP}-\mathrm{P} 101 \mathrm{~L})$ mice as a function of age. $(A)$ Expression of the MoPrP-P102L mutation produced neurologic disease in uninoculated mice. Eighteen $\operatorname{Tg}(\operatorname{PrP}-\mathrm{P} 101 \mathrm{~L}) 2247 / \mathrm{FVB}$ mice ( $\mathbf{\square})$ and $14 \mathrm{Tg}(\mathrm{PrP}-\mathrm{P} 101 \mathrm{~L}) 2862 / \mathrm{FVB}$ mice (-) were observed for the spontaneous development of neurologic disease. $|B|$ Age of onset of CNS dysfunction was modified by the wild-type MoPrP gene and the level of expression of the mutant MoPrP-P101L transgene. Twenty-five $\operatorname{Tg}\left(\mathrm{MoPrP}-\mathrm{P} 101 \mathrm{~L}^{+/ 0} \mid 2866 / \mathrm{FVB}\right.$

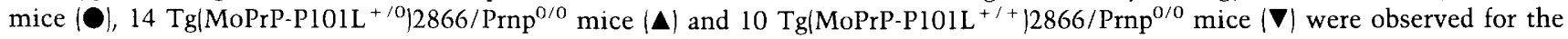
spontaneous development of neurologic disease. The curve for ages of onset of illness of two additional groups of 11 and $22 \mathrm{Tg}(\mathrm{MoPrP}-$ $\mathrm{P} 101 \mathrm{~L} / 2866 / \mathrm{Prnp}^{0 / 0}$ mice bred $>1$ year later $(\bullet$ and $\mathbf{D})$ is superimposable on the initial curve. The + superscript denotes the number of copies of the MoPrP-P101L transgene array.

expected these mice to exhibit spontaneous illness at a younger age than the eightfold overexpressors; instead, they remained well up to 250 days of age, and a few survived for more than 400 days (Fig. 1A). It is possible that the $\sim 32$-fold overexpression of $\operatorname{PrP}$ as measured by dot blot, overestimates the concentration of $\operatorname{PrP}^{\mathrm{C}}$ that is correctly folded so as to render it eligible for conversion into $\operatorname{Pr} \mathrm{P}^{\mathrm{sc}}$.

Although the $\mathrm{Tg}(\mathrm{MoPrP}-\mathrm{A}) 4053 / \mathrm{FVB}$ mice remained free of CNS dysfunction for $>600$ days of age, 6 of 20 mice developed CNS dysfunction between 605 and 815 days of age (Table 1). At this late time, many animals were also dying of intercurrent illnesses which compli- cated diagnosis. Apart from minimal spongiform alterations in the white matter normally associated with aging in mice, no neuropathologic evidence for prion disease was evident. In addition, examination of brain extracts by Western blotting failed to detect the presence of protease-resistant $\mathrm{PrP}^{\mathrm{Sc}}$. The absence of neuropathologic features of prion disease in the brains of these mice reflects the difficulty of accurately diagnosing clinical prion disease in elderly animals.

Transgenic mice expressing similar levels of MoPrP with an $\mathrm{E}$ to $\mathrm{K}$ change at residue 199, equivalent to the E200K mutation in humans that produces inherited Creutzfeldt-Jakob disease (CJD), did not develop CNS

Table 1. Age of onset of spontaneous neurologic dysfunction in uninoculated transgenic mice overexpressing mutant or wild-type MoPrP

\begin{tabular}{|c|c|c|c|}
\hline Transgenic line $e^{a}$ & $\begin{array}{l}\text { Expressed mouse } \\
\text { PrP molecules }\end{array}$ & $\begin{array}{l}\text { PrP transgene } \\
\text { expression }^{\mathrm{b}}\end{array}$ & 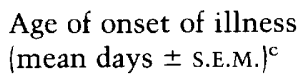 \\
\hline $\operatorname{Tg}(\mathrm{MoPrP}-\mathrm{A}) 4053 / \mathrm{FVB}$ & wt & $\times 8$ & $744 \pm 31(6 / 20)$ \\
\hline Tg(MoPrP-E199K)5182/FVB & wt, E199K & $\times 8$ & $704 \pm 61(7 / 20)$ \\
\hline Tg(MoPrP-P101L)2247/FVB & $w t, P 101 L$ & $\times 8$ & $227 \pm 16(17 / 17)$ \\
\hline Tg(MoPrP-P101L)2866/FVB & $w t, P 101 L$ & $\times 8$ & $220 \pm 10(18 / 18)$ \\
\hline Tg(MoPrP-Pl01L/2866/Prnp ${ }^{0 / 0}$ & P101L & $\times 8$ & $146 \pm 2(14 / 14)$ \\
\hline Tg(MoPrP-P10lL $L^{+/+} / 2866 /$ Prnp $^{0 / 0}$ & P101L & N.D. & $85 \pm 2(10 / 10)$ \\
\hline $\operatorname{Tg}(\mathrm{MoPrP}-\mathrm{P} 101 \mathrm{~L}) 2862 / \mathrm{FVB}$ & $w t, P 101 L$ & $\times 32$ & $321 \pm 21(14 / 14)$ \\
\hline
\end{tabular}

a Transgenic mice are designated according to the species of PrP expressed from the integrated transgene array. If mutant PrP constructs are expressed, the location of the mutated codon is indicated preceded by the single letter amino acid code of the wild-type codon followed by the mutant codon. Finally, the founder animal number from which the line was derived is used to distinguish individual lines.

bProtein expression relative to wild-type, nontransgenic mice.

${ }^{\mathrm{c}}$ The number of mice spontaneously developing clinical signs of scrapie divided by the original number of mice is shown in parentheses. 
disease (Table 1). A small number of these $\mathrm{Tg}(\mathrm{MoPrP}-$ E199K/5182/FVB mice were clinically diagnosed with CNS disease at the same time as $\mathrm{Tg}(\mathrm{MoPrP}-\mathrm{A}) 4053 / \mathrm{FVB}$ mice, but the brains of these transgenic mice did not exhibit any of the pathological hallmarks of prion disease, nor did they contain protease-resistant $\mathrm{PrP}^{\mathrm{Sc}}$. We conclude that, unlike $\operatorname{Tg}(\mathrm{MoPrP}-\mathrm{P} 101 \mathrm{~L})$ mice, transgenic mice expressing high levels of the mutant MoPrP form of the familial CJD (E200K) mutation do not develop CNS disease.

\section{Interactions between mutant and wild-type $M o P r P$}

Because the $\operatorname{Tg}($ MoPrP-P101L)/FVB mice express two $\mathrm{PrP}^{\mathrm{C}}$ molecules differing only at a single amino acid, residue 101, we asked how the disease process might be influenced by eliminating wild-type $\mathrm{MoPrP} \mathrm{P}^{\mathrm{C}}$. $\mathrm{Tg}(\mathrm{MoPrP}$ $\mathrm{P} 101 \mathrm{~L} / 2866 / \mathrm{Prnp}^{\mathrm{O} / 0}$ mice were produced by genetic crosses between $\mathrm{Prnp}^{\mathrm{O} / 0}$ mice and Tg(MoPrP-P101L)2866/FVB mice. Unlike Tg(MoPrP-P101L)2866/FVB mice, the $\mathrm{Tg}\left(\mathrm{MoPrP}-\mathrm{P} 101 \mathrm{~L} / 2866 / \mathrm{Prnp}^{0 / 0}\right.$ mice all became ill within a narrow interval (Fig. 1B). More than $90 \%$ of the $\operatorname{Tg}\left(\mathrm{MoPrP}-\mathrm{P} 101 \mathrm{~L} / 2866 / \mathrm{Prnp}^{\mathrm{O} / 0}\right.$ mice developed CNS dysfunction and died within a period of $\sim 21$ days whereas the $\operatorname{Tg}($ MoPrP-P101L)2866/FVB mice required 161 days. The mean age for development of neurologic disease in the $\mathrm{Tg}(\mathrm{MoPrP}-\mathrm{P} 101 \mathrm{~L}) 2866 / \mathrm{Prnp}^{\mathrm{O} / 0}$ mice was $146 \pm 2$ days ( \pm S.E.M., $n=14$ ), in contrast to 220 \pm 10 days ( \pm S.E.M., $n=25$ ) for the $\mathrm{Tg}$ (MoPrP-P101L)2866/ FVB mice (Table 1). The mean duration of illness, that is, the time from the appearance of clinical signs to death, was reduced by a factor of $>5$ from $17 \pm 3$ days in $\mathrm{Tg}$ (MoPrP-P101L)2866/FVB mice to $3 \pm 1$ days in the Tg(MoPrP-P101L)2866/Prnp ${ }^{0 / 0}$ mice. Thus, expression of wild-type $\mathrm{MoPrP}^{\mathrm{C}}$, albeit at an eight-fold lower level than mutant MoPrP-P101L, profoundly affected the progression of disease in $\mathrm{Tg}(\mathrm{MoPrP}-\mathrm{P} 101 \mathrm{~L})$ mice. When additional groups of $\mathrm{Tg}(\mathrm{MoPrP}-\mathrm{P} 101 \mathrm{~L}) 2866 / \mathrm{Prnp}^{\mathrm{O} / 0}$ mice were observed more than a year after the initial studies described above were performed, the curves for ages of onset of illness in these mice were superimposable on that of the initial study and the mean ages for development of neurologic disease were $149 \pm 7$ days ( \pm S.E.M., $n=11)$ and $137 \pm 3$ days $(n=22)$ (Fig. 1B).

By mating $\mathrm{Tg}(\mathrm{MoPrP}-\mathrm{P} 101 \mathrm{~L}) 2866 / \mathrm{Prnp}^{0 / 0}$ mice to each other, we produced offspring that were homozygous for the MoPrP-P101L transgene array. These mice, designated $\mathrm{Tg}\left(\mathrm{MoPrP}-\mathrm{P} 101 \mathrm{~L}^{+/+} \mid 2866 / \mathrm{Prnp}^{\mathrm{O} / 0}\right.$, had a mean age for the onset of neurologic disease of $85 \pm 2$ days ( \pm S.E.M., $n=10$ ) as well as an abbreviated clinical course (Table 1; Fig. 1B).

Transmission of CNS disease: further evidence for interference between mutant and wild-type MoPrP

Brain homogenates prepared from $\mathrm{Tg}(\mathrm{MoPrP}-101 \mathrm{~L}) 2247 /$ FVB and Tg(MoPrP-P101L)2866/FVB mice that had spontaneously developed signs of neurologic disease were inoculated intracerebrally into $\mathrm{Tg}(\mathrm{MoPrP}-\mathrm{P} 101 \mathrm{~L})$ 196/FVB and $\operatorname{Tg}(\mathrm{MoPrP}-\mathrm{P} 101 \mathrm{~L}) 196 / \mathrm{Prnp}^{\mathrm{O} / \mathrm{o}}$ mice. Both $\mathrm{Tg}(\mathrm{Mo}-$
PrP-P101L/196 lines express low levels of MoPrPC. (P101L) whereas Tg(MoPrP-P101L)196/Prnp ${ }^{0 / 0}$ mice do not express wild-type $\mathrm{MoPrP}^{\mathrm{C}}$ which is found in $\mathrm{Tg} / \mathrm{Mo}^{-}$ PrP-P101L)196/FVB mice. Uninoculated Tg(MoPrPP101L)196/FVB and Tg(MoPrP-P101L)196/Prnp ${ }^{0 / 0}$ mice did not spontaneously develop CNS disease [Table 2, (Hsiao et al. 1994)]. Tg(MoPrP-P101L)196/FVB mice inoculated with seven different brain homogenates from spontaneously ill $\mathrm{Tg}(\mathrm{MoPrP}-\mathrm{P} 101 \mathrm{~L}) 2247 / \mathrm{FVB}$ or $\mathrm{Tg}(\mathrm{Mo}-$

Table 2. Transmission of mutant prions produced in $\mathrm{Tg}(\mathrm{MoPrP}-\mathrm{P} 101 \mathrm{~L})$ mice to inoculated recipients

\begin{tabular}{|c|c|c|}
\hline Inoculum & \multicolumn{2}{|c|}{$\begin{array}{l}\text { Incubation time } \\
\left(\text { mean days } \pm \text { s.E.M. }\left.\right|^{\text {a }}\right.\end{array}$} \\
\hline \multicolumn{3}{|c|}{ A. Recipient $\operatorname{Tg}($ MoPrP-P101L)196/FVB mice } \\
\hline None & $>750$ & $(0 / 9)$ \\
\hline $\operatorname{Tg} 2247-1$ & $389 \pm 6$ & $(10 / 10)$ \\
\hline $\operatorname{Tg} 2247-2$ & $304 \pm 11$ & $(10 / 10)$ \\
\hline $\operatorname{Tg} 2247-3$ & $324 \pm 14$ & $(9 / 10)$ \\
\hline $\operatorname{Tg} 2247-4$ & $323 \pm 12$ & $\{9 / 9\}$ \\
\hline $\operatorname{Tg} 2247-5$ & $384 \pm 37$ & $\{5 / 5\}$ \\
\hline $\operatorname{Tg} 2866-1$ & $362 \pm 14$ & $(10 / 10)$ \\
\hline $\operatorname{Tg} 2866-2$ & $336 \pm 17$ & $(9 / 9)$ \\
\hline $\operatorname{Tg} 196-1(2247-1)^{\mathrm{b}}$ & $359 \pm 13$ & $(10 / 10)$ \\
\hline $\operatorname{Tg} 196-2(2247-1)$ & $312 \pm 45$ & $(7 / 7)$ \\
\hline Non-Tg2247-1 & $>450$ & $(0 / 8)$ \\
\hline Non-Tg2247-2 & $>450$ & $(0 / 8)$ \\
\hline Non- $\operatorname{Tg} 2247-3$ & $>450$ & $\mid 0 / 16\}$ \\
\hline \multicolumn{3}{|c|}{ B. Recipient non-Tg196/FVB } \\
\hline $\operatorname{Tg} 2247-2$ & $>650$ & $|0 / 5|$ \\
\hline $\operatorname{Tg} 2247-3$ & $>600$ & $\{0 / 3)$ \\
\hline $\operatorname{Tg} 196-1(2247-1)$ & $>700$ & $(0 / 5)$ \\
\hline $\operatorname{Tg} 196-2(2247-1)$ & $>700$ & $(1 / 4)^{\mathrm{c}}$ \\
\hline \multicolumn{3}{|c|}{ C. Recipient $\operatorname{Tg}\left(\right.$ MoPrP-P101L)196/Prnp ${ }^{0 / 0}$ mice } \\
\hline None & $>750$ & $(0 / 8)$ \\
\hline $\operatorname{Tg} 2247-1$ & $190 \pm 6$ & $(9 / 9)$ \\
\hline $\operatorname{Tg} 2247-2$ & $205 \pm 6$ & $(8 / 8)$ \\
\hline $\operatorname{Tg} 2247-3$ & $182 \pm 7$ & $(9 / 9)$ \\
\hline $\operatorname{Tg} 2247-5$ & $236 \pm 28$ & $(5 / 5)$ \\
\hline $\operatorname{Tg} 196-1(2247-1)$ & $230 \pm 5$ & $(10 / 10)$ \\
\hline $\operatorname{Tg} 196-2(2247-1)$ & $257 \pm 6$ & $(10 / 10)$ \\
\hline \multicolumn{3}{|c|}{ D. Recipient non-Tg196/Prnp ${ }^{0 / 0}$ mice } \\
\hline $\operatorname{Tg} 2247-1$ & $>700$ & $(0 / 4)$ \\
\hline $\operatorname{Tg} 2247-3$ & $>700$ & $(0 / 3)$ \\
\hline $\operatorname{Tg} 2247-5$ & $>570$ & $(0 / 4)$ \\
\hline \multicolumn{3}{|c|}{ E. Recipient $\mathrm{Tg}(\mathrm{MoPrP}-\mathrm{A}) 4053 / \mathrm{FVB}$} \\
\hline $\operatorname{Tg} 196-1(2247-1)$ & $>700$ & $(0 / 7)$ \\
\hline $\operatorname{Tg} 196-2(2247-1)$ & $>350$ & $(0 / 7)$ \\
\hline \multicolumn{3}{|c|}{ F. Recipient non- $T g(M \circ P r P-A) 4053 / F V B$} \\
\hline $\operatorname{Tg} 196-1(2247-1)$ & $>700$ & $\{0 / 4\}$ \\
\hline $\operatorname{Tg} 196-2(2247-1)$ & $>650$ & $(1 / 3)^{d}$ \\
\hline
\end{tabular}

Tg(MoPrP-P101L)196 mice express the mutant MoPrP-P101L transgene at a low level and do not develop disease spontaneously (Hsiao et al. 1994).

${ }^{a}$ Notations in parentheses indicate inoculum used in initial passage.

bSingle digit following a hypen distinguishes individual mice from a particular line.

${ }^{\circ}$ One animal sick at 463 days.

${ }^{\mathrm{d}}$ One animal sick at 454 days. 
PrP-P101L/2866/FVB mice developed signs of CNS dysfunction with a mean incubation time of $\sim 350$ days ( $T a$ ble 2A). In contrast, $\mathrm{Tg}(\mathrm{MoPrP}-\mathrm{P} 101 \mathrm{~L}) 196 / \mathrm{FVB}$ mice inoculated with brain homogenates from control non$\mathrm{Tg}(\mathrm{MoPrP}-\mathrm{P} 101 \mathrm{~L}) 2247 / \mathrm{FVB}$ littermates remained free of symptoms. Transmission of neurodegeneration required expression of the MoPrP-P101L transgene because CNS disease was not transmitted to control non-Tg196/FVB or non-Tg196/PrP Prnp ${ }^{0 / 0}$ mice (Table 2C, D). These control experiments demonstrate that disease in inoculated $\mathrm{Tg}(\mathrm{MoPrP}-\mathrm{P} 101 \mathrm{~L}) 196$ mice was not caused by contaminating mouse prions.

Expression of endogenous wild-type $\mathrm{MoPrP}^{\mathrm{C}}$ in inoculated $\mathrm{Tg}(\mathrm{MoPrP}-\mathrm{P} 101 \mathrm{~L}) 196$ mice had a potent inhibitory effect on the efficiency of prion transmission. Transmission of neurodegeneration from $\mathrm{Tg}$ (MoPrP-P101L)2247/FVB mice to recipient $\mathrm{Tg}$ (MoPrP-P101L)196/Prnp ${ }^{0 / 0}$ mice occurred $\sim 200$ days after inoculation, a reduction of $\sim 40 \%$ compared to $\mathrm{Tg}$ (MoPrP-P101L)196/FVB recipients in which disease occurred at $\sim 350$ days (Table $2 B$ ).

Serial transmission from two ill $\mathrm{Tg}($ MoPrP-P101L)196/ FVB mice, designated Tg196-1(2247-1) and Tg1962(2247-1), was only observed in $\operatorname{Tg}($ MoPrP-P101L)196/ FVB and $\mathrm{Tg}(\mathrm{MoPrP}-\mathrm{P} 101 \mathrm{~L}) 196 / \mathrm{Prnp}^{\mathrm{O} / 0}$ mice expressing $\operatorname{MoPrP}(\mathrm{P} 101 \mathrm{~L})$. Transmission of $\mathrm{CNS}$ disease did not occur in inoculated nontransgenic 196/FVB mice expressing only endogenous wild-type $\mathrm{MoPrP}$ or $\mathrm{Tg}(\mathrm{MoPrP}-\mathrm{A}) 4053 / \mathrm{FVB}$ mice expressing high levels of wild-type $\operatorname{MoPrP}^{\mathrm{C}}$ (Table 2C, E), indicating that only MoGSS and not wild-type Mo prions were generated in $\mathrm{Tg}($ MoPrP-P101L)196/FVB mice inoculated with brain homogenates from spontaneously ill $\mathrm{Tg}(\mathrm{MoPrP}-\mathrm{P} 101 \mathrm{~L})$ mice. These findings provide even more persuasive evidence for de novo production of prions in mice expressing a transgene carrying the P102L mutation of GSS than that previously reported by two of us (S.B. Prusiner and S. J. DeArmond) (Hsiao et al. 1994).

\section{Neuropathology of $\mathrm{Tg}(\mathrm{MoPrP}-\mathrm{P} 101 \mathrm{~L})$ mice}

Spongiform degeneration and reactive astrocytic gliosis were found in all mice expressing the P101L mutant transgene at the time they exhibited signs of CNS dysfunction (Fig. 2A, B). Like the $\operatorname{Tg}($ MoPrP-P101L) 174 and $\mathrm{Tg}(\mathrm{MoPrP}-\mathrm{P} 101 \mathrm{~L}) 87$ mice, occasional PrP plaques were detected in the brains of a few ill $\mathrm{Tg}(\mathrm{MoPrP}-\mathrm{P} 101 \mathrm{~L}) 2866$ / FVB and Tg(MoPrP-P101L)2247/FVB mice (Fig. 2D). Unexpectedly, the brains of all ill $\mathrm{Tg}(\mathrm{MoPrP}-\mathrm{P} 101 \mathrm{~L}) 2866 /$ Prnp $^{0 / 0}$ mice examined contained abundant PrP plaques that stained with PAS and $\alpha-\operatorname{PrP}$ RO73 antiserum (Fig. 2E).

The most severe spongiform change and gliosis was found in the brains of spontaneously ill $\mathrm{Tg}(\mathrm{MoPrP}$ P101L/2862/FVB mice which overexpress mutant $\operatorname{MoPrP}(\mathrm{P} 101 \mathrm{~L}) \sim 32$-fold (Fig. 2C). Vacuolation of the globus pallidus, cerebellum, and substantia nigra was extensive. Severe vacuolation of the neocortex and caudate was also found in these $\operatorname{Tg}(\mathrm{MoPrP}-\mathrm{P} 101 \mathrm{~L}) 2862 / \mathrm{FVB}$ mice. The extreme vacuolation of cerebellar white mat- ter in $\operatorname{Tg}(\mathrm{MoPrP}-\mathrm{P} 101 \mathrm{~L}) 2862 / \mathrm{FVB}$ mice is unusual but shares some features with that reported for mice inoculated with an extract prepared from a patient dying of GSS disease (Tateishi et al. 1979). Like Tg(MoPrPP101L)2866/ $\mathrm{Prnp}^{0 / 0}$ mice, $\mathrm{Tg}(\mathrm{MoPrP}-\mathrm{P} 101 \mathrm{~L}) 2862 / \mathrm{FVB}$ mice contained abundant $\operatorname{PrP}$ plaques, although they were larger and more numerous (Fig. 2F).

The neuropathology in Tg(MoPrP-P101L)196/ $\mathrm{Prnp}^{\mathrm{O} / 0}$ mice developing CNS degeneration after inoculation with homogenates prepared from spontaneously ill $\mathrm{Tg}($ MoPrP-P101L)2247/FVB or $\mathrm{Tg}($ MoPrP-P101L)2866/ FVB mice consisted of intense reactive astrocytic gliosis, particularly in the cerebellar cortex and along the corticospinal tract (Fig. 2G, H). Spongiform degeneration was most marked in the corticospinal tract reminiscent of the neuropathology found in humans who died of GSS. PrP amyloid plaques were found in the subcallosal region in two of three brains examined from $\operatorname{Tg}(\operatorname{MoPrP}-$ P101L)196/Prnp ${ }^{0 / 0}$ mice (Fig. 2I). No PrP plaques were seen in the brains of three ill $\mathrm{Tg}(\mathrm{MoPrP}-\mathrm{P} 101 \mathrm{~L}) 196 / \mathrm{FVB}$ mice examined.

Immunoblots of brain extracts from $\mathrm{Tg}\left(\mathrm{MoPrP}\right.$-P101L)Prnp ${ }^{0 / 0}$ mice

The abundance of PrP amyloid plaques in the brains of ill $\mathrm{Tg}\left(\right.$ MoPrP-P101L)2866/Prnp ${ }^{\mathrm{O} / 0}$ mice (Fig. 2E) suggested that proteinase $\mathrm{K}$-resistant $\operatorname{PrP}$, that is $\mathrm{PrP}^{\mathrm{Sc}}$, was likely to be demonstrable by Western immunoblotting. To the contrary, no $\operatorname{PrP}$ resistant to proteinase $\mathrm{K}$ digestion was detectable in extracts prepared from the brains of $\operatorname{Tg}\left(\right.$ MoPrP-P101L)2866/Prnp ${ }^{0 / 0}$ mice (Fig. 3). From these results, we conclude that the $\operatorname{PrP}$ deposits in the brains of $\mathrm{Tg} /$ MoPrP-P101L/2866/Prnp ${ }^{0 / 0}$ mice exhibiting clinical signs of CNS dysfunction and the neuropathologic hallmarks of prion disease are not derived from proteaseresistant $\operatorname{PrP}^{\mathrm{Sc}}$ molecules.

Unable to detect proteinase K-resistant PrP by immunoblotting of brain homogenates (Fig. 3), we asked whether detergent-insoluble PrP isolated by ultracentrifugation after limited digestion with proteinase $\mathrm{K}$ might reveal protease-resistant $\operatorname{Pr} P$ molecules. Thus, we examined fractions derived from the brains of spontaneously ill or inoculated $\operatorname{Tg}(\mathrm{MoPrP}-\mathrm{P} 101 \mathrm{~L})$ mice and used as controls the brains of $\operatorname{Tg}(\mathrm{MoPrP}) 4053 / \mathrm{FVB}$ mice overexpressing wild-type MoPrP and non- $\mathrm{Tg}(\mathrm{MoPrP}-\mathrm{P} 101 \mathrm{~L})$ littermates, both of which were age-matched and well at the time of sacrifice. Both soluble and insoluble fractions were analyzed by immunoblotting after SDS-PAGE (Fig. 4). Protease-resistant PrP was found almost exclusively in the detergent-insoluble fraction of each sample; minor amounts of protease-resistant $\operatorname{PrP}$ in the soluble fraction in some samples seem likely to be attributable to mixing during removal of the supernatants. The molecular weight of the detergent-insoluble, protease-resistant $\operatorname{Pr} P$ was similar to that of $\operatorname{PrP}^{\mathrm{C}}$ at $33-35 \mathrm{kD}$, and thus, different from that of PrP 27-30 (Fig. 3). We found no correlation between the protease-resistant, insoluble $\mathrm{PrP}$ and the development of spontaneous CNS disease in Tg(MoPrP-P101L) mice; furthermore, PrP molecules with 

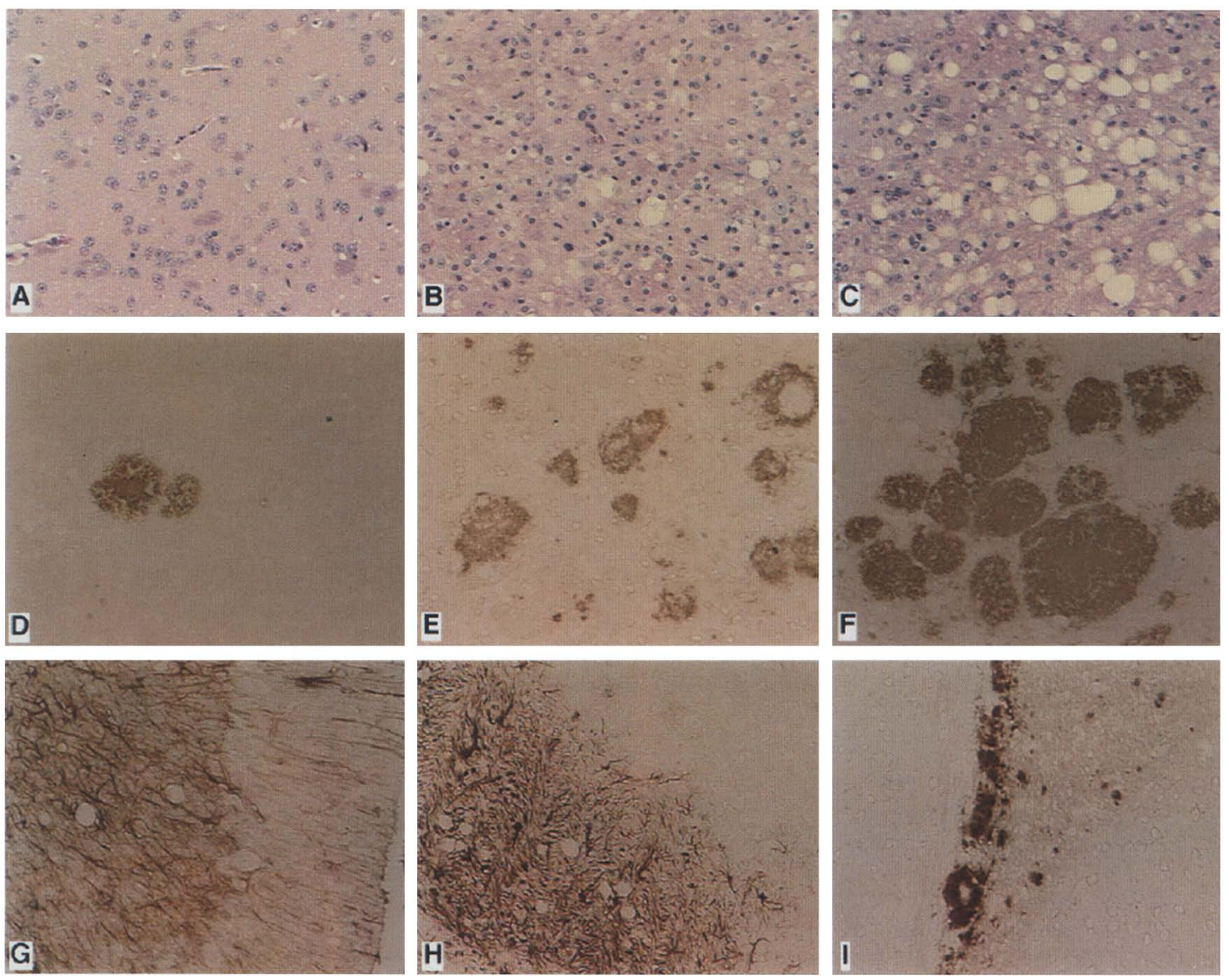

Figure 2. PrP amyloid plaques, spongiform degeneration, and reactive astrocytic gliosis in mice expressing the mutant MoPrP-P101L transgene. $(A, D) \mathrm{Tg}\left(\right.$ MoPrP-P101L)2866/FVB mouse. $(B, E) \operatorname{Tg}\left(\right.$ MoPrP-P101L)2866/Prnp ${ }^{0 / 0}$ mouse. $(C, F) \operatorname{Tg}($ MoPrP-P101L)2862/FVB mouse. $(G, I) \operatorname{Tg}\left(\right.$ MoPrP-P101L)196/Prnp ${ }^{0 / 0}$ mouse inoculated with brain homogenate from an ill $\mathrm{Tg}(\mathrm{MoPrP}-\mathrm{P} 101 \mathrm{~L}) 2247 / \mathrm{FVB}$ mouse. Sections of the globus pallidus stained with hematoxylin and eosin in $A-C$ and with immunoperoxidase using $\alpha$-PrP R073 antiserum in $D-F$ and $I .(G, H)$ The degree of reactive astrocytic gliosis is shown in sections of the cerebellar cortex $(G)$ and the internal capsule $(H)$ stained for GFAP with immunoperoxidase. Magnification, $400 \times$.

similar properties were detected in brain extracts from uninoculated $\operatorname{Tg}($ MoPrP-A) 4053/FVB mice overexpressing wild-type MoPrP as well as non- $\mathrm{Tg}(\mathrm{MoPrP}-\mathrm{P} 101 \mathrm{~L})$ littermates.

\section{Neuromyopathy in $\operatorname{Tg}($ MoPrP-P101L) mice}

Although we found no evidence of CNS degeneration in 6 of $20 \mathrm{Tg}(\mathrm{MoPrP}-\mathrm{A}) 4053 / \mathrm{FVB}$ mice dying between 605 and 815 days of age (Table 1), we examined quadriceps muscles from these aged mice, as well as clinically ill $\mathrm{Tg}(\mathrm{MoPrP}-\mathrm{P} 101 \mathrm{~L}) 2866 / \mathrm{FVB}$ mice and age-matched $\mathrm{Tg}(\mathrm{MoPrP}-\mathrm{P} 101 \mathrm{~L}) 196 / \mathrm{FVB}$ mice to ascertain whether overexpression of $\operatorname{PrP}$ in these transgenic mice caused peripheral neuropathy and myopathy similar to transgenic mice overexpressing SHa or MoPrP-B /Westaway et al. 1994). Although there was no evidence for neuromyopathic changes in the skeletal muscle of aged $\mathrm{Tg}($ MoPrP-A)4053/FVB mice, the skeletal muscles of Tg(MoPrP-P101L)87, Tg(MoPrP-P101L)174, and Tg(Mo-PrP-
P101L/2866/FVB mice exhibited neuropathic and myopathic changes concomitantly with the development of CNS disease at $\sim 200$ days of age (Fig. $5 \mathrm{~A}-\mathrm{C}$ ). Only very mild abnormalities of muscle and peripheral nerve were found in $\operatorname{Tg}($ MoPrP-P101L)196/FVB mice sacrificed at the same age.

Skeletal muscle from clinically ill $\operatorname{Tg}($ MoPrPP101L/2866/FVB mice revealed marked type I fiber predominance and grouping (dark muscle fibers in right two-thirds of the photomicrograph, Fig. 5A) indicative of neurogenic rearrangement of muscle fiber types with a relatively normal distribution of type I and II muscle fibers in the left one-third. Occasional degenerating muscle fibers were observed with rare fibers undergoing phagocytosis (Fig. 5B, arrow). Muscle from age-matched Tg(MoPrP-P101L)196/FVB mice showed normal numbers and distribution of type I and II fibers, whereas the diameter of the type I fibers (darkly stained) appeared to be, on the average, about $10 \mu \mathrm{m}$ less than the diameter of type I fibers in normal mice (Fig. 5D). Examination of 


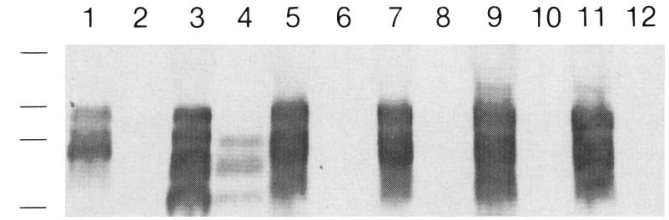

Figure 3. Western blot of brain homogenates from transgenic mice expressing MoPrP with the P101L mutation that causes GSS. $\operatorname{Tg}($ MoPrP-P101L) mice developed neurologic dysfunction spontaneously. Aliquots of brain homogenates of ill mice were either treated (odd-numbered lanes) or digested with $20 \mu \mathrm{g}$ proteinase $\mathrm{K}$ for $60 \mathrm{~min}$ at $37^{\circ} \mathrm{C}$ (even-numbered lanes). Samples were analyzed as described above except $\alpha-\operatorname{PrP}$ RO73 antiserum was used. (Lanes 1, 2) Uninoculated CD-1 mouse; (lanes 3, 4) non-transgenic mouse inoculated with RML Mo prions that showed signs of illness after 128 days; (lanes 5, 6) Tg(MoPrPP101L) 2866/FVB mouse spontaneously ill at 213 days; (lanes 7 . 8) Tg(MoPrP-P101L)2862/FVB mouse spontaneously sick at 333 days; (lanes 9, 10) Tg(MoPrP-P101L)2247/FVB mouse spontaneously ill at 160 days; (lanes 11,12$) \mathrm{Tg}($ MoPrP-P101L) 2866/ Prnp $^{0 / 0}$ mouse spontaneously ill at 138 days. The positions of protein molecular weight markers are shown to the left of the blot and correspond to molecular masses of (from top to bottom) $45,31,21$, and $14 \mathrm{kD}$.

muscle from aged $\mathrm{Tg}$ (MoPrP-A)4053/FVB mice revealed no abnormalities in type I and II fiber size or distribution (Fig. 5E). The NADH staining (Fig. 5C) revealed subsarcolemmal accumulation of mitochondria, verified by the Gomori trichrome stain (ragged red fibers) and succinic dehydrogenase stain (latter two not shown), and abnormalities in the distribution of the sarcoplasmic reticulum (motheaten fibers). Pathological changes in sciatic nerve were found in $\mathrm{Tg}(\mathrm{MoPrP}-\mathrm{P} 101 \mathrm{~L} / 2866 / \mathrm{FVB}$ mice and included regional loss of axons and active Wallerian degeneration (Fig. 6). The muscle fiber-type grouping abnormalities shown in Figure 5 is related to the axonal degeneration shown in Figure 6. The degenerating fibers, mitochondrial hyperplasia, and motheaten fibers are myopathic features, and suggest that high expression of MoPrP-P101L, but not wild-type MoPrP, causes abnormalities of skeletal muscle both directly and indirectly via peripheral nerve.

\section{Abbreviated scrapie incubation times in $\operatorname{Tg}(\mathrm{MoPr} P-A)$ mice}

Studies with $\operatorname{Tg}(\mathrm{SHaPrP})$ mice demonstrated that the level of SHaPrPC expression was inversely related to the length of the incubation time (Prusiner et al. 1990). As expected, $\operatorname{Tg}(\mathrm{MoPrP}-\mathrm{A}) 4053 / \mathrm{FVB}$ mice expressing high levels of MoPrP $\mathrm{P}^{\mathrm{C}} \mathrm{A}$ exhibited abbreviated incubation times of $\sim 45$ days after inoculation with mouse RML prions (Table 3A). The duration of illness was also shortened. Homogenates from two ill $\mathrm{Tg}(\mathrm{MoPrP}-\mathrm{A}) 4053 / \mathrm{FVB}$ mice, designated RML(4053-1) and RML/4053-2) produced incubation times that were indistinguishable from those of RML prions passaged in CD-1 Swiss mice or $\mathrm{Tg}(\mathrm{MoPrP}-\mathrm{A}) 4053 / \mathrm{FVB}$ mice showing that passage through $\mathrm{Tg}(\mathrm{MoPrP}-\mathrm{A}) 4053 / \mathrm{FVB}$ mice did not alter the strain characteristics of RML. By mating $\mathrm{Tg}(\mathrm{MoPrP}-$ A) $4053 / \mathrm{FVB}$ mice with $\mathrm{Prnp}^{0 / 0}$ mice, we produced a line of mice in which the MoPrP-A transgene was expressed in the absence of endogenous mouse Prnp alleles. Scrapie incubation times in these $\mathrm{Tg} / \mathrm{MoPrP}$ A) $4053 / \mathrm{Prnp}^{\mathrm{O} / 0}$ mice inoculated with RML prions was prolonged by $\sim 10$ days compared to $\operatorname{Tg}($ MoPrP-A $) 4053$ / FVB mice reflecting the diminished level of PrP-A expression (Table 3A).

The brains of ill Tg(MoPrP-A)4053/FVB mice inoculated with RML prions showed substantially reduced spongiform degeneration and reactive astrocytic gliosis compared to those of nontransgenic mice (Fig. 7). Whether the shorter incubation time of $\mathrm{Tg}(\mathrm{MoPrP}-$
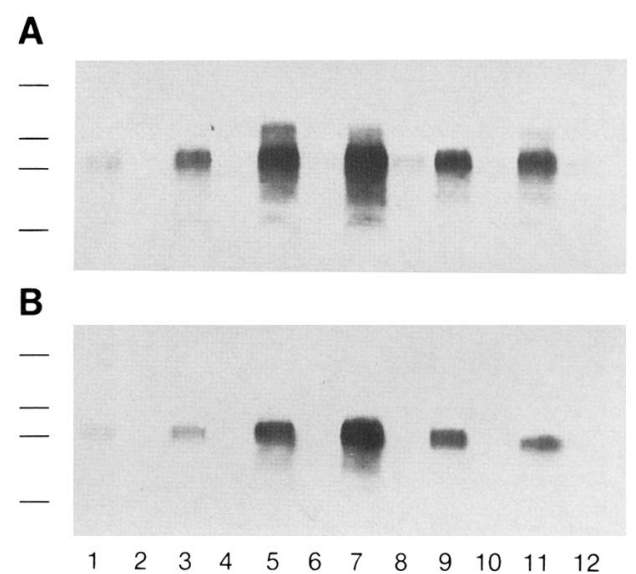

Figure 4. The presence of detergent-insoluble, protease-resistant PrP in mouse brain does not correlate with disease in spontaneously ill or inoculated $\operatorname{Tg}(\operatorname{MoPrP}-\mathrm{P} 101 \mathrm{~L})$ mice. Brain homogenates were adjusted to $100 \mu \mathrm{g}$ total protein $/ \mathrm{ml}$ in TNE $(10$ $\mathrm{mM}$ Tris at $\mathrm{pH} 8.0,150 \mathrm{~mm} \mathrm{NaCl}, 1 \mathrm{~mm}$ EDTA) containing $0.2 \%$ sarkosyl and proteinase $\mathrm{K}$ was added at a final concentration of either $10 \mu \mathrm{g} / \mathrm{ml}|A|$ or $100 \mu \mathrm{g} / \mathrm{ml}|B|$. Digestion was allowed to proceed for $\mathrm{l} \mathrm{hr}$ at $37^{\circ} \mathrm{C}$ and was terminated by addition of 100 mM PMSF. Insoluble aggregates were pelleted by centrifugation at $100,000 \times g$ for $1 \mathrm{hr}$. Pellets from the high speed centrifugation were resuspended in cell lysis buffer containing $0.5 \%$ NP-40, $0.5 \%$ deoxycholic acid, $150 \mathrm{~mm} \mathrm{NaCl}$ and $10 \mathrm{~mm}$ Tris- $\mathrm{HCl}$, at $\mathrm{pH} 8.0$ and added to an equal volume of $2 \times$ SDS-PAGE loading buffer. The supernatants following ultracentrifugation were concentrated by precipitation at $-20^{\circ} \mathrm{C}$ in $5 \mathrm{vol}$ of methanol followed by centrifugation at $3700 \times g$ for $15 \mathrm{~min}$. Pellets from this low speed centrifugation were also resuspended in cell lysis buffer and added to an equal volume of $2 \times$ SDS-PAGE loading buffer. The samples were analyzed by SDS-PAGE and Western blotting using the $\alpha-\operatorname{PrP}$ RO73 antiserum. Odd numbered lanes are sedimented samples from the high-speed centrifugation, even numbered lanes are supernatants. The lanes are as follows: (Lanes 1, 2) Non-transgenic mouse; (lanes 3, 4) $\mathrm{Tg}(\mathrm{MoPrP} \mid 4053 / \mathrm{FVB}$; (lanes 5, 6) Tg(MoPrP-P101L)2866/FVB; (lanes 7, 8) Tg(MoPrP-P101L)2247/FVB; (lanes 9, 10) Tg(MoPrPP101L)2862/FVB; (lanes 11, 12) Tg(MoPrP-P101L)196/FVB mice inoculated with MoPrP-P101L prions from a spontaneously sick Tg(MoPrP-P101L)2247/FVB mouse. The sizes of molecular mass markers from top to bottom are $85.0,50.3,33.3$, and $28.5 \mathrm{kD}$. 


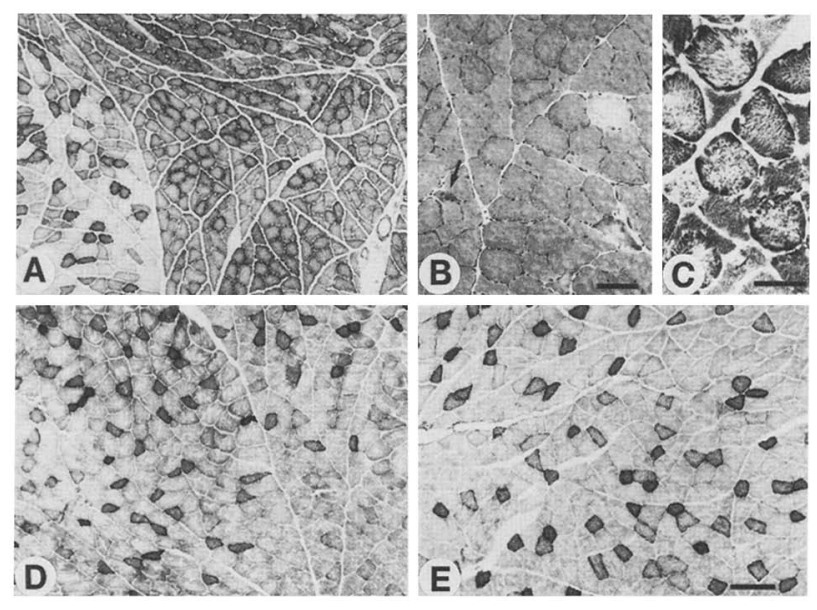

Figure 5. Skeletal muscle in $\mathrm{Tg}(\mathrm{MoPrP}-\mathrm{P} 101 \mathrm{~L})$ mice expressing high levels of the mutant MoPrP transgene develop a neuromyopathy. Only mild abnormalities were found in the muscles or peripheral nerves of well, age-matched $\mathrm{Tg}(\mathrm{MoPrP}$ P101L)196 mice expressing low levels of the mutant PrP transgene. No abnormalities were found in the muscles or peripheral nerves of well $\mathrm{Tg}(\mathrm{MoPrP}-\mathrm{A}) 4053 / \mathrm{FVB}$ mice expressing high levels of wild-type MoPrP at 700 days of age. (A) The NADH histochemical stain reveals marked type I fiber predominance and grouping (dark muscle fibers in right two-thirds of the photomicrograph) indicative of neurogenic rearrangement of muscle fiber types with a relatively normal distribution of type I and II muscle fibers in the left one-third. (B) The hematoxylin and eosin-stained section reveals occasional degenerating muscle fibers with a rare fiber undergoing phagocytosis (arrow). (C) The higher power photomicrograph of the NADHstained section shows subsarcolemmal accumulation of mitochondria, verified by the Gomori trichrome stain (ragged red fibers) and succinic dehydrogenase stain (latter two not shown), and abnormalities in the distribution of the sarcoplasmic reticulum (motheaten fibers). The degenerating fibers, mitochondrial hyperplasia and motheaten fibers are myopathic features and suggest that high expression of the MoPrP-P101L transgene causes abnormalities of skeletal muscle directly as well as indirectly via peripheral nerve. $(D)$ The cytochromeoxidase histochemical stain of a low expressor $\mathrm{Tg}(\mathrm{MoPrP}$ P101L)196/FVB mouse muscle shows normal numbers of type I and II fibers and a normal distribution pattern. The diameter of the type I fibers (darkly stained) are, on the average, about $10 \mu \mathrm{m}$ less than the diameter of type I fibers in normal mice. $(E)$ The NADH stain of an old $\mathrm{Tg}$ (MoPrP-A)4053/FVB shows no abnormalities in type I and II fiber size or distribution. The quadriceps femoris was examined in each case. Bar in $E, 100 \mu \mathrm{m}$ and also applies to $A$ and $D$; bars in $B$ and $C, 50 \mu \mathrm{m}$.

A)4053/FVB mice compared to nontransgenic controls is responsible, at least in part, for the reduced neuropathology, remains to be determined. Western blot analysis of brain homogenates from ill $\mathrm{Tg}(\mathrm{MoPrP}-\mathrm{A}) 4053 / \mathrm{FVB}$ mice inoculated with RML prions had less $\mathrm{PrP}^{\mathrm{Sc}}$ than inoculated nontransgenic littermates (Fig. 8). Although the patterns of $\mathrm{PrP}^{\mathrm{Sc}}$ deposition were similar in scrapied $\mathrm{Tg}$ (MoPrP-A)4053/FVB and nontransgenic mice, histoblots showed lower levels of $\mathrm{PrP}^{\mathrm{Sc}}$ in the brains of ill $\mathrm{Tg}(\mathrm{Mo}-$ PrP-A/4053/FVB than in nontransgenic mice (data not shown).

\section{Discussion}

The development of a mouse model for human GSS (P102L) has substantially increased our understanding of the inherited prion diseases. Although we were initially concerned about the infrequency of PrP amyloid plaques, the lack of protease-resistant $\operatorname{PrP}$, and transmission of disease to a minority of inoculated recipients with extremely prolonged incubation times (Hsiao et al. 1990, 1994), each of those concerns has been addressed as described here. From our results, we conclude that $\mathrm{Tg}(\mathrm{Mo}-$ PrP-P101L / mice faithfully recapitulate virtually all features of human GSS (P102L).

Transgenic mice that overexpress wild-type $\mathrm{MoPrP}^{\mathrm{C}}$ at the same level as mutant $\mathrm{MoPrPC}(\mathrm{P} 101 \mathrm{~L})$ demonstrate clearly that the P101L mutation is required for CNS degeneration. Our studies also demonstrate a profound suppressive influence of wild-type $\mathrm{MoPrP}^{\mathrm{C}}$ on both the clinical and neuropathologic features of the GSS phenotype. The inhibitory effects of wild-type $\mathrm{MoPrP}^{\mathrm{C}}$ were manifest in multiple ways: First, ablation of the wildtype MoPrP gene significantly modifies the clinical symptoms of spontaneously sick $\mathrm{Tg}(\mathrm{MoPrP}-\mathrm{P} 101 \mathrm{~L})$ mice, changing the age of onset of CNS disease from a relatively stochastic process in $\mathrm{Tg}(\mathrm{MoPrP}-\mathrm{P} 101 \mathrm{~L} / \mathrm{FVB}$ mice to a highly uniform process in $\mathrm{Tg}(\mathrm{MoPrP}-\mathrm{P} 101 \mathrm{~L})$ $\mathrm{Prnp}^{\mathrm{o} / 0}$ mice (Fig. 1). Second, expression of endogenous

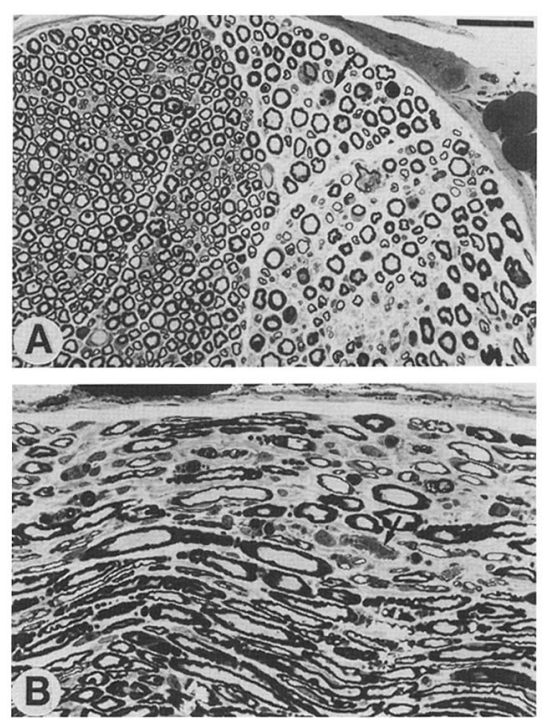

Figure 6. Pathological features of sciatic nerves from $\mathrm{Tg} / \mathrm{Mo}-$ PrP-P101L/ mice include regional loss of axons and active Wallerian degeneration. $|A|$ Cross section of a nerve fascicle showing normal numbers and density of axons to the left and reduction in the number of axons with occasional degenerating axons on the right. $(B)$ Longitudinal section of the same nerve fascicle shows multiple degenerating axons in the upper half of the photomicrograph and normal axons in the lower half. Arrows in $A$ and $B$ indicate examples of axonal degeneration. The muscle fiber type grouping shown in Fig. 5 is related to the axonal degeneration demonstrated in this figure. One-micron-thick plastic section of nerve stained with toluidine blue. Bar in $A, 50$ $\mu \mathrm{m}$ and also applies to $B$. 
Table 3. Prion incubation times in $\operatorname{Tg}(\operatorname{MoPr} P-A)$ mice

\begin{tabular}{|c|c|c|c|}
\hline \multirow[b]{2}{*}{ Recipient mice } & \multirow[b]{2}{*}{ Inoculum $^{a}$} & \multicolumn{2}{|c|}{$\begin{array}{c}\text { Incubation times } \\
\text { (mean days } \pm \text { S.E.M.) }\end{array}$} \\
\hline & & Illness ${ }^{\mathrm{b}}$ & Death $^{\mathrm{c}}$ \\
\hline \multicolumn{4}{|l|}{ A. $\operatorname{Tg}(\operatorname{Pr} P-A)$ mice } \\
\hline $\operatorname{Tg}($ MoPrP-A) $4053 /$ FVB & RML & $48 \pm 1(21 / 21)$ & $53 \pm 2(12)$ \\
\hline $\mathrm{Tg}(\mathrm{MoPrP}-\mathrm{A}) 4053 / \mathrm{FVB}$ & Tg4053-2 (RML) & $48 \pm 2(10 / 10)$ & $58 \pm 2(7)$ \\
\hline Non- $\mathrm{Tg} 4053$ & RML & $127 \pm 2(18 / 18)$ & $156 \pm 2\langle 5\rangle$ \\
\hline $\operatorname{Tg}($ MoPrP-A $) 4053 / \operatorname{Prnp}^{0 / 0}$ & RML & $59 \pm 2(9 / 9)$ & $65 \pm 2(6)$ \\
\hline \multicolumn{4}{|l|}{ B. Swiss $C D-1$ mice } \\
\hline Swiss CD- ${ }^{\mathrm{d}}$ & RML & $138 \pm 1(24 / 24)$ & $159 \pm 3(24)$ \\
\hline Swiss CD-1 & Tg4053-1 (RML) & $140 \pm 3(10 / 10)$ & $163 \pm 2(6)$ \\
\hline Swiss CD-1 & Tg4053-2 (RML) & $138 \pm 5(9 / 9)$ & $169 \pm 2(6)$ \\
\hline
\end{tabular}

${ }^{a}$ Notation in parentheses indicates inoculum used in initial passage. Single digit following a hyphen distinguishes individual mice from a particular line.

${ }^{b}$ The number of mice developing clinical signs of scrapie is shown in parentheses.

${ }^{\mathrm{c}}$ The number of mice dying of scrapie is shown in parentheses. Mice sacrificed for pathologic examination were excluded from these calculations.

${ }^{\mathrm{d} D a t a}$ from Butler et al. (1988).

wild-type MoPrP caused the clinical phase of disease to be more protracted in $\operatorname{Tg}(\mathrm{MoPrP}-\mathrm{P} 101 \mathrm{~L})$ mice. Third, elimination of endogenous wild-type $\mathrm{MoPrP}^{\mathrm{C}}$ expression modified the neuropathology of $\operatorname{Tg}(\operatorname{MoPrP}-\mathrm{P} 101 \mathrm{~L})$ mice: Whereas relatively few PrP plaques could be detected in $\mathrm{Tg}(\operatorname{MoPr}$-P101L)FVB mice, there was widespread deposition of $\operatorname{PrP}$ amyloid plaques in $\operatorname{Tg}(\mathrm{MoPrP}-\mathrm{P} 101 \mathrm{~L})$ $\mathrm{Prnp}^{\mathrm{O} / \mathrm{O}}$ mice in addition to spongiform degeneration (Fig. 2). Fourth, elimination of wild-type $\mathrm{MoPrP}^{\mathrm{C}}$ expression rendered $\operatorname{Tg}($ MoPrP-P101L)196 mice more susceptible to GSS prions from spontaneously sick $\mathrm{Tg}(\mathrm{MoPrP}$ P101L) mice, manifested by a $\sim 40 \%$ reduction of GSS prion incubation times in inoculated $\mathrm{Tg}(\mathrm{MoPrP}-\mathrm{P} 101 \mathrm{~L})$ 196/Prnp ${ }^{0 / 0}$ mice compared to $\mathrm{Tg}(\operatorname{MoPrP}-\mathrm{P} 101 \mathrm{~L}) 196 /$ FVB recipients (Table 2).

\section{Transmission of de novo generated prions}

The transmission experiments reported here demonstrate unequivocally the formation of infectious prions in the brains of spontaneously ill $\mathrm{Tg}(\mathrm{MoPrP}-\mathrm{P} 101 \mathrm{~L})$ mice and, in conjunction with many other lines of experimental investigation, continue to militate for the absence of a nucleic acid within the prion particle (Prusiner 1991; Prusiner 1982). The reproducible transmission of neurodegeneration from $\mathrm{Tg}(\mathrm{MoPrP}-\mathrm{P} 101 \mathrm{~L})$ mice and not from control nontransgenic mice (Table 2) rules out the trivial possibility of transmission by contamination. Although low level expression of the MoPrP-P101L transgene does not cause spontaneous neurodegeneration in $\mathrm{Tg} / \mathrm{MoPrP}$ P101L)196/FVB or Tg(MoPrP-P101L)196/Prnp ${ }^{0 / 0}$ mice after $>750$ days (Table 2), efficient transmission of mutant P101L prions requires expression of MoPrP-P101L in these recipient mice. Prions produced de novo in Tg(MoPrP-P101L)2247/FVB mice did not transmit disease to nontransgenic mice which only express wild-type Mo$\operatorname{PrP}$ or to $\operatorname{Tg}($ MoPrP-A) $4053 / F V B$ mice which overexpress wild-type MoPrP and are highly sensitive to wildtype mouse prions.
Transgenetic studies argue that $\operatorname{PrP}^{\mathrm{C}}$ and $\mathrm{PrP}^{\mathrm{Sc}}$ form a complex during the conversion of $\operatorname{PrP}^{\mathrm{C}}$ into nascent $\operatorname{PrP}^{\mathrm{Sc}}$ (Prusiner et al. 1990; Scott et al. 1993). The data reported here underscore the results of human CJD and GSS prion transmissions in $\mathrm{Tg}(\mathrm{MHu} 2 \mathrm{M}) 5378$ and $\mathrm{Tg}(\mathrm{MHu} 2 \mathrm{M}-\mathrm{P} 102 \mathrm{~L}) 69$ mice which argue that prion prop-

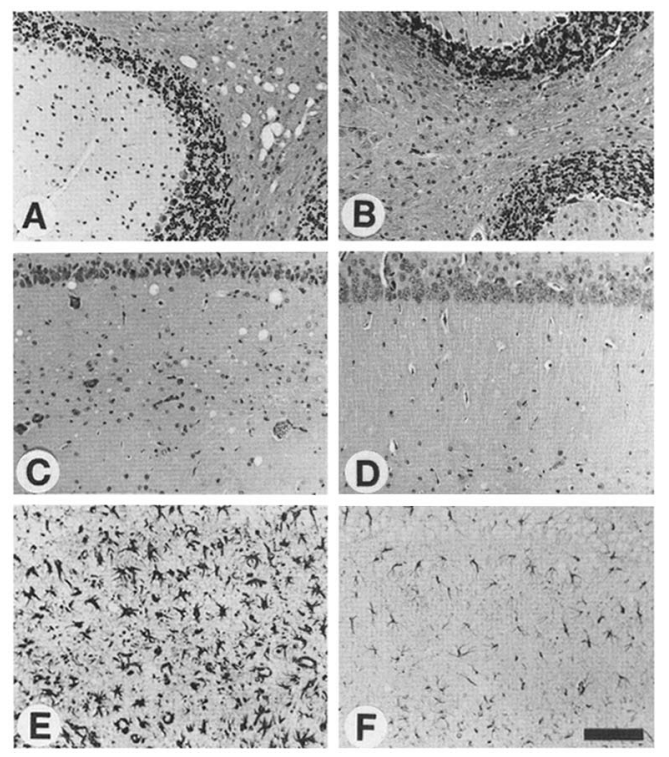

Figure 7. The intensity of spongiform degeneration and reactive astrocytic gliosis in the brains of $\mathrm{Tg}(\mathrm{MoPrP}-\mathrm{A}) 4053 / \mathrm{FVB}$ mice and non-transgenic littermates inoculated with mouse RML prions. Mice were sacrificed when they showed signs of CNS dysfunction. $(A, C, E)$ Brain sections from inoculated nontransgenic mice. $(B, D, F)$ Brain sections from inoculated $\mathrm{Tg}($ MoPrP-A) $4053 / \mathrm{FVB}$ mice. $A$ and $B$ are hematoxylin and eosin stained sections showing spongiform degeneration in the cerebellum while panels $C$ and $D$ are hematoxylin and eosin stained sections showing spongiform degeneration in the hippocampus. GFAP immunohistochemistry was performed on sections through the hippocampus and show reactive astrocytic gliosis in $E$ and $F$. Bar, $100 \mu \mathrm{M}$. 


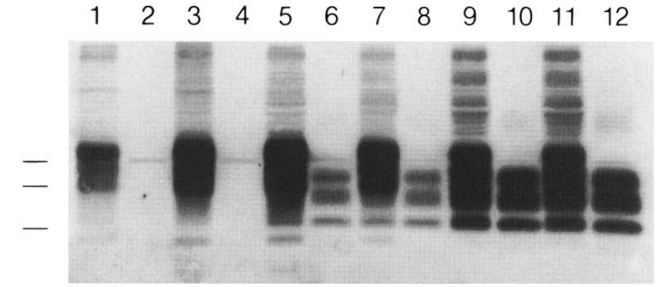

Figure 8. $\operatorname{Pr}^{\mathrm{C}}$ and $\operatorname{PrP}^{\mathrm{Sc}}$ in the brains of ill $\operatorname{Tg}(\mathrm{MoPrP}-\mathrm{A})$ 4053/ FVB mice and non-transgenic mice inoculated with mouse RML prions. The total concentrations of protein in $10 \%$ brain homogenates were determined by bicinchoninic acid assay. Aliquots of brain homogenates containing equal amounts of total protein in each case were either treated with $20 \mu \mathrm{g}$ of proteinase $\mathrm{K}$ for $60 \mathrm{~min}$ at $37^{\circ} \mathrm{C}$ (even-numbered lanes) or not treated (oddnumbered lanes). Samples were resolved by SDS-PAGE and analyzed by Western blot. The blot was exposed to the $\alpha-\operatorname{PrP}$ RO73 antiserum, developed using enhanced chemiluminescence (ECL) and exposed to X-ray film. $(1,2)$ Uninoculated CD-1 mouse $(3,4)$ uninoculated $\mathrm{Tg}(\mathrm{MoPrP}-\mathrm{A}) 4053 / \mathrm{FVB}$ mouse; $(5,6)$ $\mathrm{Tg}($ MoPrP-A)4053/FVB mouse inoculated with mouse RML prions sick at 48 days; $(7,8) \mathrm{Tg}$ (MoPrP-A)4053/FVB mouse inoculated with mouse RML prions sick at 56 days; $(9,10)$ non-transgenic littermate inoculated with mouse RML prions sick at 128 days; $(11,12)$ non-transgenic littermate inoculated with mouse RML prions sick at 125 days. The positions of protein molecular weight markers are shown to the left of the blot and correspond to molecular masses of (from top to bottom) 31, 21, and $14 \mathrm{kD}$.

agation is facilitated by homology within the central domains of $\mathrm{HuPrP}^{\mathrm{C}}$ and $\mathrm{HuPrP}^{\mathrm{Sc}}$ (Telling et al. 1995). Since wild-type MoPrP and MoPrP-P101L differ only at a single amino acid position, these results further demonstrate that prion propagation is facilitated by homology between $\operatorname{PrP}^{C}$ and $\operatorname{PrP}^{\mathrm{Sc}}$ and that mismatch at residue 101 inhibits this process. This conclusion is strengthened by the results of serial passaging experiments which demonstrate that prions produced de novo in the brains of $\mathrm{Tg}(\mathrm{MoPrP}-\mathrm{P} 101 \mathrm{~L})$ mice discriminate between wild-type $\mathrm{MoPrP}^{\mathrm{C}}$ and $\mathrm{MoPrP}^{\mathrm{C}}(\mathrm{P} 101 \mathrm{~L})$ expressed in $\mathrm{Tg}(\mathrm{MoPrP}-$ P101L)196/FVB mice. In these transgenic mice, MoPrPP101L prions, but not wild-type mouse prions, were produced as demonstrated by serial passage. Furthermore, expression of endogenous wild-type $\mathrm{MoPr}^{\mathrm{C}}$ in inoculated $\mathrm{Tg}(\mathrm{MoPrP}-\mathrm{P} 101 \mathrm{~L}) 196$ mice had a potent inhibitory effect on the efficiency of MoPrP-P101L prion transmission.

\section{Absence of protease-resistant PrP in diseased $\mathrm{Tg}(\mathrm{MoPrP}-\mathrm{P} 101 \mathrm{~L})$ mice}

Although earlier studies had shown an excellent correlation between the level of protease-resistant $\mathrm{PrP}^{\mathrm{Sc}}$ (McKinley et al. 1983) and scrapie prion infectivity, making it a good marker for disease, we were unable to detect protease-resistant $\operatorname{PrP}^{\mathrm{Sc}}$ in these spontaneously ill mice or in inoculated $\mathrm{Tg}(\mathrm{MoPrP}-\mathrm{P} 101 \mathrm{~L}) 196$ mice. Whether additional studies using lower concentrations of proteinase $\mathrm{K}$ for very brief periods of time (Lehmann and Harris 1996) will demonstrate a meaningful difference between mutant PrP from ill Tg(MoPrP-P101L) mice and controls such as uninoculated $\operatorname{Tg}(\mathrm{MoPrP}-\mathrm{A})$ and $\mathrm{Tg}(\mathrm{MoPrP}-$ P101L/196 mice remains to be determined. In earlier studies, we observed some protease-resistant $\operatorname{PrP}$ in brain extracts prepared from uninoculated $\mathrm{Tg}(\mathrm{SHaPrP})$ mice overexpressing SHaPrP when low concentrations of proteinase $\mathrm{K}$ were used for digestions (Prusiner et al. 1990). To differentiate what seems to be incompletely digested $\mathrm{PrP}^{\mathrm{C}}$ from protease-resistant $\mathrm{PrP}^{\mathrm{Sc}}$, we routinely used high concentrations of proteinase K. Since the mutant $\operatorname{Pr} \mathrm{P}(\mathrm{P} 101 \mathrm{~L})$ molecules clearly convey prion infectivity (Table 2), we conclude in accord with earlier studies (Hsiao et al. 1994) that the absence of proteaseresistant $\mathrm{PrP}^{\mathrm{Sc}}$ does not rule out prion disease, even though the presence of protease-resistant $\operatorname{PrP}^{\mathrm{Sc}}$ is considered a diagnostic marker for the prion diseases (Prusiner and Hsiao 1994).

The absence of detectable protease-resistant $\mathrm{PrP}^{\mathrm{Sc}}$ does not, however, preclude its presence in the infectious prion. The sensitivity of the bioassay for prion detection is several orders of magnitude greater than for the detection of $\mathrm{PrP}^{\mathrm{Sc}}$. An alternative explanation for our inability to detect protease-resistant $\operatorname{PrP}^{\mathrm{Sc}}$ in the brains of $\operatorname{Tg}(\operatorname{MoPrP}-\mathrm{P} 101 \mathrm{~L})$ mice is that the titer of infectious prions in ill $\operatorname{Tg}(\operatorname{MoPrP}-\mathrm{P} 101 \mathrm{~L})$ mice is below the level for detection of protease-resistant $\mathrm{PrP}^{\mathrm{Sc}}$. Experiments designed to determine accurately the titer of prions in these mice by endpoint titration are underway and should resolve this issue. Such studies should also help determine whether infectivity generated in $\mathrm{Tg}(\mathrm{MoPrP}$ $\mathrm{P} 101 \mathrm{~L}$ ) mice is resistant or sensitive to protease treatment.

Similar to our $\operatorname{Tg}\left(\right.$ MoPrP-P101L)2866/Prnp ${ }^{0 / 0}$ mice (Fig. 2), the brains of patients who die from GSS (P102L) always contain $\operatorname{PrP}$ amyloid plaques, yet detectable protease-resistant PrP is not a constant feature (Telling et al. 1995). Although brain tissue from GSS (P102L) often transmits disease to inoculated recipients, this is also not a constant feature (Masters et al. 1981; Brown et al. 1994; Tateishi and Kitamoto 1995). Whether all cases of GSS (P102L) will transmit disease to $\mathrm{Tg}(\mathrm{MHu} 2 \mathrm{M}-\mathrm{P} 102 \mathrm{~L})$ mice expressing a mutant, chimeric $\mathrm{Hu} / \mathrm{Mo} \operatorname{PrP}$ transgene remains to be established (Telling et al. 1995). It is also of interest that the brains of patients who die of inherited CJD (E200K) have two forms of insoluble PrP; the mutant $\operatorname{PrP}$ is protease resistant, and the wild-type is sensitive to protease digestion (Gabizon et al. 1996). Yet, both the mutant and wild-type insoluble PrP can be distinguished from $\operatorname{PrP}^{\mathrm{C}}$ which is soluble in non-denaturing detergents.

\section{The P101L mutation causes neurodegeneration and neuromyopathy}

The fact that overexpression of wild-type PrP can produce neurodegeneration of the CNS as well as neuromyopathy (Westaway et al. 1994) prompted us to re-examine neurodegeneration in $\mathrm{Tg}(\mathrm{MoPrP}-\mathrm{P} 101 \mathrm{~L})$ mice (Hsiao et al. 1990). The inclusion of additional control transgenic mice which overexpress wild-type MoPrP at levels 
equivalent to mutant $\operatorname{PrP}$ in $\operatorname{Tg}($ MoPrP-P101L) mice demonstrates that the P101L mutation, not merely overexpression of $\mathrm{PrP}$, causes the clinical and neuropathologic features of GSS. It is noteworthy that in addition to neurodegeneration of the CNS, skeletal muscle in high expressor $\mathrm{Tg}(\mathrm{MoPrP}-\mathrm{P} 101 \mathrm{~L})$ lines developed severe neuropathic and myopathic changes at the time they developed CNS disease (Fig. 5). Features of amyotrophy with muscle fasiculations and fibrillations have been reported in an Italian kindred with GSS (P102L) (Kretzschmar et al. 1992), and the proband from a large English pedigree with GSS, in addition to neurogenic atrophy, showed muscle pathologic changes (Rosenthal et al. 1976). Immunostaining studies have localized PrP at neuromuscular junctions in humans (Askanas et al. 1993) but mice deficient for $\mathrm{PrP}^{\mathrm{C}}$ have been shown to exhibit normal electrical transmission at the neuromuscular junction (Brenner et al. 1992). Whether neuromyopathic changes are an integral feature of human GSS (P102L) remains to be established.

Aged mice overexpressing either wild-type SHaPrP or the Prnp ${ }^{\mathrm{b}}$ allele develop hind limb paresis as a result of a necrotizing myopathy and a demyelinating peripheral neuropathy (Westaway et al. 1994). In contrast, aged mice overexpressing the Prnp ${ }^{a}$ allele showed no evidence of hind limb paresis or pathologic changes in skeletal muscle or peripheral nerves. The mechanism by which overexpression of mutant as well as foreign wild-type transgenes cause neuromyopathies is unknown. Perhaps, heterologous PrPs expressed in Prnp ${ }^{a}$ FVB mice tend to misfold more frequently than do homologous PrP molecules. $\mathrm{SHaPrP}$ differs from $\mathrm{MoPrP}$ at 16 of 254 amino acid residues (Basler et al. 1986; Locht et al. 1986), MoPrP-B and MoPrP-A differ at amino acid residues 108 and 189 (Westaway et al. 1987), and MoPrP-P101L and MoPrP-A differ at a single residue.

\section{Modifying the disease phenotypes of $\mathrm{Tg}(\operatorname{MoPr} P-P 101 \mathrm{~L})$ mice}

Variations in the phenotypes of dominantly inherited neurologic diseases have often been attributed to the interplay of gene products other than that which carries the disease-causing mutation. Two new mechanisms have been discovered recently, and a third is reported here. First, the triplet repeat diseases, such as myotonic dystrophy and Huntington's chorea, exhibit phenotypic variation with respect to the age of onset that depends upon the number of repeats (Fu et al. 1992; Huntington's Disease Collaborative Research Group 1993). In general, there is an inverse relationship between the number of repeats and the age of onset; this finding provided a molecular basis for the phenomenon called anticipation. Second, the inherited prion diseases caused by a D178N mutation of the PrP gene present as dementing illnesses or insomnia, depending upon the polymorphic residue codon 129 (Goldfarb et al. 1992; Monari et al. 1994). When V129 is encoded on the mutant allele, patients present with a dementia; M129 presents as insomnia. Other PrP mutations at codons 102, 105, and 198 often present with ataxia (Dlouhy et al. 1992; Kitamoto et al. 1993|, while the codon 200 mutation seems to present invariably as a dementia (Gabizon et al. 1993). Why a few members of a large pedigree with the codon 102 mutation present with a dementia is unknown (Hsiao et al. 1989).

The studies presented here show that the clinical and neuropathologic phenotypes of transgenic mice can be dramatically altered by ablation of the wild-type $\mathrm{MoPrP}$ gene. $\operatorname{Tg}(\mathrm{MoPrP}-\mathrm{P} 101 \mathrm{~L})$ mice that harbor the wild-type MoPrP gene exhibit variable times of onset of neurologic disease ranging from 150 to 300 days followed by a clinical phase of illness lasting almost three weeks (Fig. 1). The neuropathology of these mice shows spongiform degeneration and relatively few PrP plaques. In contrast, $>90 \%$ of $\mathrm{Tg}(\mathrm{MoPrP}-\mathrm{P} 101 \mathrm{~L}) / \mathrm{Prnp}^{0 / 0}$ mice develop clinical signs of CNS dysfunction within a period of $\sim 21$ days and have a short duration of illness lasting $\sim 3$ days. The neuropathology of these mice not only shows spongiform degeneration but also widespread deposition of $\operatorname{PrP}$ amyloid plaques (Fig. 2). Crossing these mice to produce animals homozygous for the mutant transgene array produced spontaneous disease at $\sim 85$ days of age (Fig. 1A). Just as expression of wild-type MoPrP dramatically altered the clinical and neuropathologic phenotypes of $\mathrm{Tg}$ (MoPrP-P101L) mice, expression of endogenous wildtype MoPrP in recipient $\operatorname{Tg}(\mathrm{MoPrP}-\mathrm{P} 101 \mathrm{~L}) 196$ mice had a potent inhibitory effect on the efficiency of Mo prion transmission (Tab. 2).

Our results are consistent with a model in which mutant and wild-type $\operatorname{PrP}^{\mathrm{C}}$ bind to an additional component required for prion propagation, which we have designated protein X (Telling et al. 1995). Presumably, protein $\mathrm{X}$ facilitates the conversion of $\mathrm{MoPrP}^{\mathrm{C}}(\mathrm{P} 101 \mathrm{~L})$ into $\mathrm{PrP}^{\mathrm{Sc}}$. The elimination of wild-type $\mathrm{MoPrP}^{\mathrm{C}}$ expression converts the pathogenesis from what appears to be a stochastic one in $\operatorname{Tg}(\mathrm{MoPrP}-\mathrm{P} 101 \mathrm{~L}) / \mathrm{FVB}$ mice into a highly regulated process in $\mathrm{Tg}(\mathrm{MoPrP}-\mathrm{P} 101 \mathrm{~L}) / \mathrm{Prnp}^{0 / 0}$ mice. This change in prion disease pathogenesis is characterized by a narrowing of the range of ages at which neurologic dysfunction is initially manifest and an abbreviated duration of illness. Mutant and wild-type $M o P r P^{C}$ differ only at one amino acid residue likely to lie outside the putative binding site for protein $\mathrm{X}$, thought to reside at the carboxy-terminus of $\operatorname{PrPC}^{\mathrm{C}}$ (Telling et al. 1995). It remains to be determined if the inhibitory effect of relatively low levels of wild-type $\mathrm{MoPrP}^{\mathrm{C}}$ on inherited prion disease pathogenesis is a result of competition between mutant and wild-type MoPrP for binding to protein X.

\section{Determinants of CNS pathogenesis in $\mathrm{Tg}($ MoPrP-P101L) mice}

The numerous PrP amyloid plaques in the brains of $\mathrm{Tg}$ (MoPrP-P101L)2862/FVB and $\mathrm{Tg}($ MoPrP-P101L)2866/ $\mathrm{Prnp}^{\mathrm{O} / 0}$ mice (Fig. 2) is particularly important since it clearly documents an abnormality in PrP structure and metabolism, despite the absence of demonstrable protease-resistant $\mathrm{PrP}^{\mathrm{Sc}}$ on Western blots (Fig. 3). Demon- 
strating $\operatorname{Pr} \mathrm{P}^{\mathrm{Sc}}$ in the brains of some patients, particularly those dying of inherited prion diseases, has also been problematic (Brown et al. 1986; Medori et al. 1992).

The large numbers of PrP amyloid plaques in the brains of $\mathrm{Tg}($ MoPrP-P101L/2862/FVB and $\mathrm{Tg}$ (MoPrP$\mathrm{P} 101 \mathrm{~L} / 2866 / \mathrm{Prnp}^{0 / 0}$ mice suggest that mutant $\operatorname{PrPC}^{\mathrm{C}}$ is being refolded into molecules with substantial $\beta$-sheet content (Huang et al. 1996). Although FTIR and CD spectroscopy have clearly demonstrated that a major conformational change occurs during the conversion of wildtype $\operatorname{PrP}^{\mathrm{C}}$ into $\mathrm{PrP}^{\mathrm{Sc}}$ (Pan et al. 1993), no data on the secondary or tertiary structure of $\operatorname{PrP}(\mathrm{P} 101 \mathrm{~L})$ is yet available.

From data presented here, it appears that the number of $\mathrm{PrP}$ amyloid plaques may be directly proportional to the age of onset of neurologic dysfunction and to the ratio of mutant: wild-type $\mathrm{MoPrPC}$. $\mathrm{Tg}\left(\mathrm{MoPrP}-\mathrm{P} 101 \mathrm{~L}^{+1}\right.$ $+12866 /$ Prnp $^{0 / 0}$ mice homozygous for the PrP transgene array exhibit a reduced number of PrP amyloid plaques compared to mice that are hemizygous for the transgene array (data not shown) even though they presumably express twice as much MoPrPC $(\mathrm{P} 101 \mathrm{~L})$. These homozygous Tg(MoPrP-P101L $\mathrm{L}^{+/+} / 2866 /$ Prnp $^{\text {O/O }}$ mice develop CNS disease at $\sim 85$ days of age compared to hemizygous mice that become ill at $\sim 145$ days (Tab. 1). This finding argues that sufficient time must elapse for PrP amyloid deposition to occur. The hypothesis that age of onset of illness is a factor is supported by our finding that $\operatorname{Tg}(\mathrm{MoPrP}$ P101L/2862/FVB mice with numerous PrP amyloid plaques (Fig. 2) that express much higher levels of mutant $\operatorname{PrP}^{\mathrm{C}}$ and live longer than $\mathrm{Tg}(\mathrm{MoPrP}-\mathrm{P} 101 \mathrm{~L}) 2866 /$ FVB mice. While the Tg(MoPrP-P101L)2862/FVB mice express $\sim 32$-fold more mutant $\mathrm{MoPrP}^{\mathrm{C}}$ than wild-type $M o P r P^{C}$, this high ratio of mutant wild-type $\operatorname{MoPrP}^{\mathrm{C}}$ is similar to that in $\mathrm{Tg}(\mathrm{MoPrP}-\mathrm{P} 101 \mathrm{~L}) 2866 / \mathrm{Prnp}^{\mathrm{O} / 0}$ mice.

Whether factors other than the age of onset and the ratio of mutant to wild-type $\mathrm{MoPrP}^{\mathrm{C}}$ influence pathogenesis remains to be established. Why the $\mathrm{Tg}(\mathrm{MoPrP}-$ P101L/2862/FVB mice exhibit such a late onset of disease (Fig. 1) is unclear, as they have the highest levels of expression of $\mathrm{MoPrP}^{\mathrm{C}}(\mathrm{P} 101 \mathrm{~L})$ and the most severe disease neuropathologically with respect to spongiform degeneration, astrocytic gliosis, and $\mathrm{PrP}$ amyloid deposition (Fig. 2). It seems likely that either the measured $\sim 32$-fold overexpression of $\operatorname{PrP}$ overestimates the concentration of correctly folded $\mathrm{PrP}^{\mathrm{C}}$ that is eligible for conversion into $\mathrm{PrP}^{\mathrm{Sc}}$, or that insertion of the MoPrPP101L transgene into the genome of the $\mathrm{Tg}(\mathrm{MoPrP}-$ P101L/2862/FVB mouse alters the expression of a chromosomal gene that modulates the onset of illness. Because both the $\operatorname{Tg}($ MoPrP-P101L)2247/FVB and Tg(MoPrP-P101L)2286/FVB lines of mice express lower levels of $\mathrm{MoPrPC}(\mathrm{P} 101 \mathrm{~L})$ and develop signs of CNS dysfunction more rapidly, additional lines with high levels of $\mathrm{MoPrP}^{\mathrm{C}}(\mathrm{P} 101 \mathrm{~L})$ need to be constructed in order to study this conundrum.

\section{New approaches arising from these studies}

The transmission of CNS degeneration from ill $\mathrm{Tg}$ (Mo-
PrP-P101L)2247/FVB and Tg(MoPrP-P101L)2866/FVB mice to $\mathrm{Tg}($ MoPrP-P101L)196/FVB and $\mathrm{Tg}(\mathrm{MoPrP}$ P101L/196/Prnp ${ }^{0 / 0}$ mice and subsequent serial transmissions not only provides convincing evidence for de novo generation of prions but also a new system for studies of genetic and infectious prion disease. The relatively short incubation times of $\sim 200$ days in $\operatorname{Tg}($ MoPrP-P101L)196/ $\operatorname{Prnp}^{0 / 0}$ mice inoculated with mutant prions (Table 1) make characterization of these prions produced de novo feasible for the first time.

Studies of the kinetics of plaque formation in $\mathrm{Tg}\left(\mathrm{Mo}^{-}\right.$ PrP-P101L/2866/ $\operatorname{Prnp}^{\mathrm{o} / 0}$ mice are likely to give important insights into the pathogenesis of the inherited human prion diseases. To our knowledge, this is the first animal model of a dominantly inherited neurologic disease in which the onset of illness is sufficiently uniform that animals sacrificed at different times in the study can be compared, as has been done in studies of rodents inoculated with scrapie prions. Tg(MoPrP-P101L)2866 and Tg(MoPrP-P101L)2247 mice may be useful models for evaluating gene therapy for the inherited human prion diseases. Mating $\mathrm{Tg}($ MoPrP-P101L)2866 or Tg(MoPrPP101L)2247 with Tg(MoPrP-A)4053 mice that overexpress wild-type PrP-A may prevent neurodegeneration or substantially delay the onset of disease. Alternatively, the uniformity of onset of clinical signs in $\mathrm{Tg}(\mathrm{MoPrP}$ P101L/2866/ Prnp $^{0 / 0}$ mice may provide a testable model for evaluating pharmaceuticals that either stabilize $\operatorname{PrP}^{\mathrm{C}}$ or inhibit the conversion of $\operatorname{PrP}^{\mathrm{C}}$ into $\mathrm{PrP}^{\mathrm{Sc}}$ (Cohen et al. 1994). Thus, the transgenic mice described here may provide models for developing and evaluating effective treatments to prevent or ameliorate inherited neurodegenerative diseases.

\section{Materials and methods}

Production of transgenic mice

The MoPrP-A sequence used in this study was derived from C57BL mice (Locht et al. 1986; Westaway et al. 1987). Construction of the MoPrP ORF cassette has been described previously (Rogers et al. 1991). The construction of the MoPrP-P101L expression cassette containing a substitution of a leucine for proline codon at residue 101 of the MoPrP gene, corresponding to the GSS mutation at codon 102 of the human PrP gene, has been described (Hsiao et al. 1990). ORF cassettes were digested with BglII which cleaves immediately adjacent to the initiation codon. The $5^{\prime}$ protruding termini were filled in because of Klenow, and SalI linkers were added. Recombinant clones were cleaved with SalI and XhoI which cleaves immediately past the PrP termination codon, and purified ORF fragments were ligated to the SalI-cut cosSHa.Tet cosmid expression vector (Scott et al. 1992). The isolation of recombinant cosmid clones was achieved by methods that have been described previously (Scott et al. 1993). NotI fragments, recovered from large-scale DNA cosmid preparations, were used for microinjection into the pronuclei of fertilized FVB/N oocytes as previously described (Scott et al. 1989). Genomic DNA isolated from tail tissue of weanling animals was screened for the presence of incorporated transgenes using a probe that hybridizes to the 3 -untranslated region of the $\mathrm{SHaPrP}$ gene contained in the cosSHa.Tet vector (Scott et al. 1992). 


\section{Preparation of brain homogenates}

Ten percent (wt/vol) homogenates of mouse brain were prepared by repeated extrusion through an 18-gauge syringe needle followed by extrusion through a 22-gauge needle in phosphate buffered saline (PBS) lacking calcium and magnesium ions. For immunoblot analysis, samples were cleared of cell debris by a brief low-speed centrifugation.

\section{Sources of prion inocula}

The RML isolate from Swiss mice (Chandler 1961) was provided by Dr. William Hadlow (Rocky Mountain Laboratory, Hamilton, Montana) and was passaged in Swiss mice from a closed colony at the Rocky Mountain Laboratory (Hamilton, MT) or in Swiss CD-1 mice obtained from Charles River Laboratories (Wilmington, MA). For transmission of neurodegeneration from spontaneously sick $\mathrm{Tg}(\mathrm{MoPrP}-\mathrm{P} 101 \mathrm{~L})$ mice, brain homogenates were prepared as described above.

\section{Determination of incubation periods}

Mice were inoculated intracerebrally with $30 \mu \mathrm{l}$ of brain extract using a 27-gauge needle inserted into the right parietal lobe, and observed for signs of disease. Additionally, uninoculated $\mathrm{Tg}(\mathrm{MoPrP}-\mathrm{P} 101 \mathrm{~L})$ and $\mathrm{Tg}(\mathrm{MoPrP}-\mathrm{A})$ mice were observed for spontaneous CNS disease. The preparation of inocula and criteria for diagnosis of scrapie in mice have been described (Carlson et al. 1986). When clinical signs of CNS dysfunction appeared, the mice were examined daily. To confirm the clinical diagnosis, the brains of some animals whose death was obviously imminent were taken for histopathological studies.

\section{Immunoblotting}

Total protein concentrations in brain homogenates were determined by bicinchoninic acid assay. Immuno dot blots for the determination of the relative levels of PrP expression in transgenic mouse brains were performed as described previously (Scott et al. 1993). Samples for Western blot analyses were prepared as described in the figure legends. Western blots were performed as described previously (Towbin et al. 1979; Barry and Prusiner 1986), except that an enhanced chemiluminescent (ECL) detection method (Amersham, Arlington Heights, IL) was used. The blot was exposed to X-ray film. $\alpha$-PrP rabbit RO73 antiserum was used at a final dilution of 1:5000.

\section{Immunohistochemistry}

For immunohistochemistry, endogenous peroxidase activity was blocked with methanol-hydrogen peroxide $(2 \mathrm{ml}$ of $30 \%$ $\mathrm{H}_{2} \mathrm{O}_{2}$ in $200 \mathrm{ml}$ methanol). To enhance PrP immunoreactivity, the sections were immersed in $1.3 \mathrm{mM} \mathrm{HCl}$ and autoclaved at $121^{\circ} \mathrm{C}$ for $10 \mathrm{~min}$ (Muramoto et al. 1992). When the temperature decreased, the slides were placed under running tap water for 10 min followed by rinsing with $\mathrm{TB}(50 \mathrm{~mm}$ Tris- $\mathrm{HCl}$ at $\mathrm{pH} 7.6$, with $150 \mathrm{~mm} \mathrm{NaCl}$. Nonspecific protein binding was blocked with TBS $(25 \mathrm{mM}$ Tris- $\mathrm{HCl}$ at $\mathrm{pH} 7.6,0.05 \%$ Tween $20,0.5 \mathrm{M}$ $\mathrm{NaCl}, 5 \%$ nonfat milk) for $10 \mathrm{~min}$. The $\alpha$-PrP polyclonal rabbit R073 antiserum was diluted 1:250 in TBS. Tissue sections were incubated with the primary antiserum overnight at $4^{\circ} \mathrm{C}$. Following two rinses with $\mathrm{TB}$ containing $0.1 \%$ Triton-X and once in $\mathrm{TB}$, the sections were incubated with biotinylated goat antirabbit IgG (Vector Laboratories, Burlingame, CA) in TBS, 1:100 dilution, for $30 \mathrm{~min}$ at room temperature. After two rinses with $\mathrm{TB}$ containing $0.1 \%$ Triton-X, the sections were incubated with an avidin/biotin/peroxidase complex (Vector Laboratories) for $30 \mathrm{~min}$ at room temperature. Three rinses in TB were then followed by a $3-5 \mathrm{~min}$ reaction with diaminobenzadine solution (5 mg diaminobenzadine tetrahydrocholoride, $68 \mathrm{mg}$ imidazole, and $7 \mathrm{mg}$ of $\mathrm{NaN}_{3}$ in $10 \mathrm{ml}$ of $\mathrm{TB}$ ), to which $100 \mu \mathrm{l}$ of $0.0015 \%$ $\mathrm{H}_{2} \mathrm{O}_{2}$ was added.

Peroxidase immunohistochemistry with antibodies to glial fibrillary acidic protein was used to evaluate reactive astrocytic gliosis.

\section{Neuropathology}

CNS, sciatic nerve and skeletal muscle pathologies were assessed by standard procedures (Scott et al. 1989; Westaway et al. 1994).

\section{Acknowledgments}

This work was supported by grants from the National Institutes of Health (NIH)(NS14069, AG08967, AG02132, NS22786, and AG10770) and the American Health Assistance Foundation, as well as by a gift from the Sherman Fairchild Foundation. G.T. was supported by a fellowship from an NIH postdoctoral training grant (NS07219).

The publication costs of this article were defrayed in part by payment of page charges. This article must therefore be hereby marked "advertisement" in accordance with 18 USC section 1734 solely to indicate this fact.

\section{References}

Askanas, V., M. Bilak, W.K. Engel, A. Leclerc, and F. Tom. 1993. Prion protein is strongly immunolocalized at the postsynaptic domain of human normal neuromuscular junctions. Neurosci. Lett. 159: 111-114.

Barry, R.A. and S.B. Prusiner. 1986. Monoclonal antibodies to the cellular and scrapie prion proteins. I. Infect. Dis. 154: 518-521.

Basler, K., B. Oesch, M. Scott, D. Westaway, M. Wälchli, D.F. Groth, M.P. McKinley, S.B. Prusiner, and C. Weissmann. 1986. Scrapie and cellular $\operatorname{PrP}$ isoforms are encoded by the same chromosomal gene. Cell 46: 417-428.

Brenner, H. R., A. Herczeg, and B. Oesch. 1992. Normal development of nerve-muscle synapses in mice lacking the prion protein gene. Proc. R. Soc. Lond. B. 250: 151-155.

Brown, P., M. Coker-Vann, K. Pomeroy, M. Franko, D.M. Asher, C.J. Gibbs, Jr., and D.C. Gajdusek. 1986. Diagnosis of Creutzfeldt-Jakob disease by Western blot identification of marker protein in human brain tissue. N. Engl. J. Med. 314: 547-551.

Brown, P., L.G. Goldfarb, and D.C. Gajdusek. 1991. The new biology of spongiform encephalopathy: Infectious amyloidoses with a genetic twist. Lancet 337: 1019-1022.

Brown, P., C.J. Gibbs, Jr., P. Rodgers-Johnson, D.M. Asher, M.P. Sulima, A. Bacote, L.G. Goldfarb, and D.C. Gajdusek. 1994. Human spongiform encephalopathy: The National Institutes of Health series of 300 cases of experimentally transmitted disease. Ann. Neurol. 35: 513-529.

Büeler, H., M. Fischer, Y. Lang, H. Bluethmann, H.-P. Lipp, S.J. DeArmond, S.B. Prusiner, M. Aguet, and C. Weissmann. 1992. Normal development and behaviour of mice lacking the neuronal cell-surface PrP protein. Nature 356: 577-582.

Büeler, H., A. Aguzzi, A. Sailer, R.-A. Greiner, P. Autenried, M. Aguet, and C. Weissmann. 1993. Mice devoid of PrP are resistant to scrapie. Cell 73: 1339-1347. 
Butler, D.A., M.R.D. Scott, J.M. Bockman, D.R. Borchelt, A. Taraboulos, K.K. Hsiao, D.T. Kingsbury, and S.B. Prusiner. 1988. Scrapie-infected murine neuroblastoma cells produce protease-resistant prion proteins. J. Virol. 62: 1558-1564.

Carlson, G.A., P. Goodman, D.T. Kingsbury, and S.B. Prusiner. 1986. Scrapie incubation time and prion protein genes are linked. Clin. Res. 34: 675A.

Chandler, R.L. 1961. Encephalopathy in mice produced by inoculation with scrapie brain material. Lancet 1: 1378-1379.

Cohen, F.E., K.-M. Pan, Z. Huang, M. Baldwin, R.J. Fletterick, and S.B. Prusiner. 1994. Structural clues to prion replication. Science 264: 530-531.

Dlouhy, S.R., K. Hsiao, M.R. Farlow, T. Foroud, P.M. Conneally, P. Johnson, S.B. Prusiner, M.E. Hodes, and B. Ghetti. 1992. Linkage of the Indiana kindred of Gerstmann-SträusslerScheinker disease to the prion protein gene. Nat. Genet. 1: $64-67$.

Fu, Y.-H., D.P.A. Kuhl, A. Pizzuti, M. Pieretti, J.S. Sutcliffe, S. Richards, A.J.M.H. Verkerk, J.J.A. Holden, R.G. Fenwick, Jr., S.T. Warren, B.A. Oostra, D.L. Nelson, and Caskey, C.T. 1992. An unstable triplet repeat in a gene related to myotonic muscular dystrophy. Science 255: 1256-1259.

Gabizon, R., H. Rosenmann, Z. Meiner, I. Kahana, E. Kahana, Y. Shugart, J. Ott, and S.B. Prusiner. 1993. Mutation and polymorphism of the prion protein gene in Libyan Jews with Creutzfeldt-Jakob disease. Am. J. Hum. Genet. 33: 828-835.

Gabizon, R., G. Telling, Z. Meiner, M. Halimi, I. Kahana, and S.B. Prusiner. 1996. Insoluble wild-type and protease-resistant mutant prion protein in brains of patients with inherited prion disease. Nature Med. 2: 59-64.

Gajdusek, D. C. 1977. Unconventional viruses and the origin and disappearance of kuru. Science 197: 943-960.

Gambetti, P., P. Parchi, R.B. Petersen, S.G. Chen, and E. Lugaresi. 1995. Fatal familial insomnia and familial Creutzfeldt-Jakob disease: Clinical, pathological and molecular features. Brain Pathol. 5: 43-51.

Goldfarb, L. G., R.B. Petersen, M. Tabaton, P. Brown, A.C. LeBlanc, P. Montagna, P. Cortelli, J. Julien, C. Vital, W.W. Pendelbury, M. Haltia, P.R. Wills, J.J. Hauw, P.E. McKeever, L. Monari, B. Schrank, G.D. Swergold, L. Autilio-Gambetti, D.C. Gajdusek, E. Lugaresi, and P. Gambetti. 1992. Fatal familial insomnia and familial Creutzfeldt-Jakob disease: Disease phenotype determined by a DNA polymorphism. Science 258: 806-808.

Group, T.H.s.D.C.R. 1993. A novel gene containing a trinucleotide repeat that is expanded and unstable on Huntington's disease chromosomes. Cell 72: 971-983.

Hsiao, K., H.F. Baker, T.J. Crow, M. Poulter, F. Owen, J.D. Terwilliger, D. Westaway, J. Ott, and S.B. Prusiner. 1989. Linkage of a prion protein missense variant to Gerstmann-Sträussler syndrome. Nature 338: 342-345.

Hsiao, K.K., M. Scott, D. Foster, D.F. Groth, S.J. DeArmond, and S.B. Prusiner. 1990. Spontaneous neurodegeneration in transgenic mice with mutant prion protein. Science 250: $1587-1590$.

Hsiao, K. K., D. Groth, M. Scott, S.-L. Yang, H. Serban, D. Rapp, D. Foster, M. Torchia, S.J. DeArmond, and S.B. Prusiner. 1994. Serial transmission in rodents of neurodegeneration from transgenic mice expressing mutant prion protein. Proc. Natl. Acad. Sci. 91: 9126-9130.

Huang, Z., S.B. Prusiner, and F.E. Cohen. 1996. Structures of prion proteins and conformational models for prion diseases. In Prions prions prions (ed. S.B. Prusiner), pp. 49-67. Springer-Verlag, Berlin, Germany.

Kitamoto, T., M. Ohta, K. Doh-ura, S. Hitoshi, Y. Terao, and J. Tateishi. 1993. Novel missense variants of prion protein in
Creutzfeldt-Jakob disease or Gerstmann-Sträussler syndrome. Biochem. Biophys. Res. Commun. 191: 709-714.

Kretzschmar, H. A., P. Kufer, G. Riethmuller, S.J. DeArmond, S.B. Prusiner, and D. Schiffer. 1992. Prion protein mutation at codon 102 in an italian family with Gerstmann-Sträussler-Scheinker syndrome. Neurology 42: 809-810.

Lehmann, S. and D.A. Harris. 1996. Mutant and infectious prion proteins display common biochemical properties in cultured cells. J. Biol. Chem. 271: 1633-1637.

Locht, C., B. Chesebro, R. Race, and J.M. Keith. 1986. Molecular cloning and complete sequence of prion protein cDNA from mouse brain infected with the scrapie agent. Proc. Natl. Acad. Sci. 83: 6372-6376.

Manson, J. C., A.R. Clarke, P.A. McBride, I. McConnell, and J. Hope. 1994. PrP gene dosage determines the timing but not the final intensity or distribution of lesions in scrapie pathology. Neurodegeneration 3: 331-340.

Masters, C. L., D.C. Gajdusek, and C.J. Gibbs, Jr. 1981. Creutzfeldt-Jakob disease virus isolations from the Gerstmann-Sträussler syndrome. Brain 104: 559-588.

McKinley, M. P., D.C. Bolton, and S.B. Prusiner. 1983. A protease-resistant protein is a structural component of the scrapie prion. Cell 35: 57-62.

Medori, R., H.-J. Tritschler, A. LeBlanc, F. Villare, V. Manetto, H.Y. Chen, R. Xue, S. Leal, P. Montagna, P. Cortelli, P. Tinuper, P. Avoni, M. Mochi, A. Baruzzi, J.J. Hauw, J. Ott, E. Lugaresi, L. Autilio-Gambetti, and P. Gambetti. 1992. Fatal familial insomnia, a prion disease with a mutation at codon 178 of the prion protein gene. N. Engl. J. Med. 326: 444-449.

Monari, L., S.G. Chen, P. Brown, P. Parchi, R.B. Petersen, J. Mikol, F. Gray, P. Cortelli, P. Montagna, B. Ghetti, L.G. Goldfarb, D.C. Gajdusek, E. Lugaresi, P. Gambetti, and L. Autilio-Gambetti. 1994. Fatal familial insomnia and familial Creutzfeldt-Jakob disease: Different prion proteins determined by a DNA polymorphism. Proc. Natl. Acad. Sci. 91: 2839-2842.

Muramoto, T., T. Kitamoto, J. Tateishi, and I. Goto. 1992. The sequential development of abnormal prion protein accumulation in mice with Creutzfeldt-Jakob disease. Am. J. Pathol. 140: 1411-1420.

Pan, K.-M., M. Baldwin, J. Nguyen, M. Gasset, A. Serban, D. Groth, I. Mehlhorn, Z. Huang, R.J. Fletterick, F.E. Cohen, and S.B. Prusiner. 1993. Conversion of $\alpha$-helices into $\beta$-sheets features in the formation of the scrapie prion proteins. Proc. Natl. Acad. Sci. 90: 10962-10966.

Prusiner, S.B. 1982. Novel proteinaceous infectious particles cause scrapie. Science 216: 136-144.

- 1989. Scrapie prions. Annu. Rev. Microbiol. 43: 345374.

- 1991. Molecular biology of prion diseases. Science 252: 1515-1522.

1994. Inherited prion diseases. Proc. Natl. Acad. Sci. 91: 4611-4614.

Prusiner, S.B. and K.K. Hsiao. 1994. Human prion diseases. Ann. Neurol. 35: 385-395.

Prusiner, S.B., M. Scott, D. Foster, K.-M. Pan, D. Groth, C. Mirenda, M. Torchia, S.-L. Yang, D. Serban, G.A. Carlson, P.C. Hoppe, D. Westaway, and S.J. DeArmond. 1990. Transgenetic studies implicate interactions between homologous PrP isoforms in scrapie prion replication. Cell 63: 673-686.

Prusiner, S.B., D. Groth, A. Serban, R. Koehler, D. Foster, M. Torchia, D. Burton, S.-L. Yang, and S.J. DeArmond. 1993. Ablation of the prion protein ( $\mathrm{PrP})$ gene in mice prevents scrapie and facilitates production of anti-PrP antibodies. Proc. Natl. Acad. Sci. 90: 10608-10612.

Richardson, E.P.J. and C.L. Masters. 1995. The nosology of 
Telling et al.

Creutzfeldt-Jakob disease and conditions related to the accumulation of $\mathrm{PrP}^{\mathrm{CID}}$ in the nervous system. Brain Pathol. 5: 33-41.

Ridley, R.M., H.F. Baker, and T.J. Crow. 1986. Transmissible and non-transmissible neurodegenerative disease: Similarities in age of onset and genetics in relation to aetiology. Psychol. Med. 16: 199-207.

Rogers, M., D. Serban, T. Gyuris, M. Scott, T. Torchia, and S.B. Prusiner. 1991. Epitope mapping of the Syrian hamster prion protein utilizing chimeric and mutant genes in a vaccinia virus expression system. I. Immunol. 147: 3568-3574.

Rosenthal, N.P., J. Keesey, B. Crandall, and W.J. Brown. 1976. Familial neurological disease associated with spongiform encephalopathy. Arch. Neurol. 33: 252-259.

Sakaguchi, S., S. Katamine, K. Shigematsu, A. Nakatani, R. Moriuchi, N. Nishida, K. Kurokawa, R. Nakaoke, H. Sato, K. Jishage, J. Kuno, T. Noda, and T. Miyamoto. 1995. Accumulation of proteinase K-resistant prion protein $(\operatorname{PrP})$ is restricted by the expression level of normal PrP in mice inoculated with a mouse-adapted strain of the Creutzfeldt-Jakob disease agent. J. Virol. 69: 7586-7592.

Scott, M., D. Foster, C. Mirenda, D. Serban, F. Coufal, M. Wälchli, M. Torchia, D. Groth, G. Carlson, S.J. DeArmond, D. Westaway, and S.B. Prusiner. 1989. Transgenic mice expressing hamster prion protein produce species-specific scrapie infectivity and amyloid plaques. Cell 59: 847-857.

Scott, M.R., R. Köhler, D. Foster, and S.B. Prusiner. 1992. Chimeric prion protein expression in cultured cells and transgenic mice. Protein Sci. 1: 986-997.

Scott, M., D. Groth, D. Foster, M. Torchia, S.-L. Yang, S.J. DeArmond, and S.B. Prusiner. 1993. Propagation of prions with artificial properties in transgenic mice expressing chimeric PrP genes. Cell 73: 979-988.

Sigurdsson, B. 1954. Rida, a chronic encephalitis of sheep with general remarks on infections which develop slowly and some of their special characteristics. Br. Vet. I. 110: 341354.

Tateishi, J. and T. Kitamoto. 1995. Inherited prion diseases and transmission to rodents. Brain Pathol. 5: 53-59.

Tateishi, J., M. Ohta, M. Koga, Y. Sato, and Y. Kuroiwa. 1979. Transmission of chronic spongiform encephalopathy with kuru plaques from humans to small rodents. Ann. Neurol. 5: 581-584.

Telling, G.C., M. Scott, J. Mastrianni, R. Gabizon, M. Torchia, F.E. Cohen, S.J. DeArmond, and S.B. Prusiner. 1995. Prion propagation in mice expressing human and chimeric $\operatorname{PrP}$ transgenes implicates the interaction of cellular PrP with another protein. Cell 83: 79-90.

Towbin, H., T. Staehelin, and J. Gordon. 1979. Electrophoretic transfer of proteins from polyacrylamide gels to nitrocellulose sheets: Procedure and some applications. Proc. Natl. Acad. Sci. 76: 4350-4354.

Westaway, D., P.A. Goodman, C.A. Mirenda, M.P. McKinley, G.A. Carlson, and S.B. Prusiner. 1987. Distinct prion proteins in short and long scrapie incubation period mice. Cell 51: $651-662$.

Westaway, D., S.J. DeArmond, J. Cayetano-Canlas, D. Groth, D. Foster, S.-L. Yang, M. Torchia, G.A. Carlson, and S.B. Prusiner. 1994. Degeneration of skeletal muscle, peripheral nerves, and the central nervous system in transgenic mice overexpressing wild-type prion proteins. Cell 76: 117-129. 


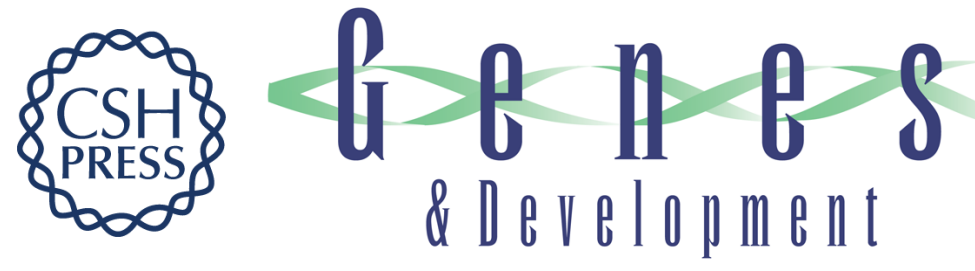

\section{Interactions between wild-type and mutant prion proteins modulate neurodegeneration in transgenic mice.}

G C Telling, T Haga, M Torchia, et al.

Genes Dev. 1996, 10:

Access the most recent version at doi:10.1101/gad.10.14.1736

References This article cites 57 articles, 19 of which can be accessed free at:

http://genesdev.cshlp.org/content/10/14/1736.full.html\#ref-list-1

License

Email Alerting

Service

Receive free email alerts when new articles cite this article - sign up in the box at the top right corner of the article or click here.

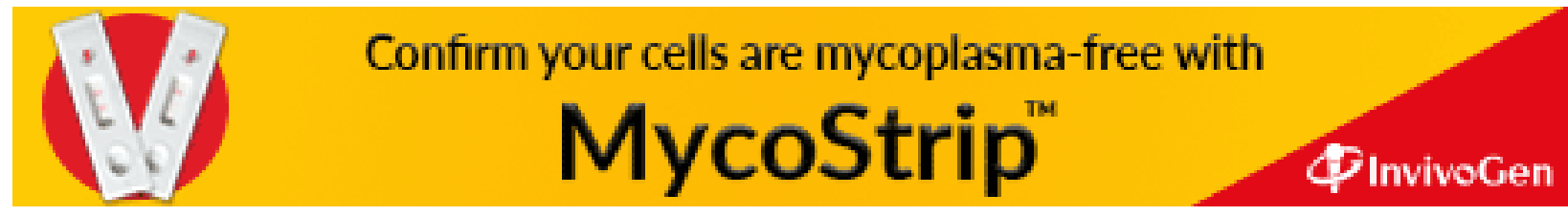

